\title{
Retrofitting Garden-Style Apartments in Brooklyn, New York
}

Heather Nolen, Sean Maxwell, Robin Neri, and Joanna Grab Consortium for Advanced Residential Buildings 


\section{NOTICE}

This report was prepared as an account of work sponsored by an agency of the United States government. Neither the United States government nor any agency thereof, nor any of their employees, subcontractors, or affiliated partners makes any warranty, express or implied, or assumes any legal liability or responsibility for the accuracy, completeness, or usefulness of any information, apparatus, product, or process disclosed, or represents that its use would not infringe privately owned rights. Reference herein to any specific commercial product, process, or service by trade name, trademark, manufacturer, or otherwise does not necessarily constitute or imply its endorsement, recommendation, or favoring by the United States government or any agency thereof. The views and opinions of authors expressed herein do not necessarily state or reflect those of the United States government or any agency thereof.

Available electronically at SciTech Connect http:/www.osti.gov/scitech

Available for a processing fee to U.S. Department of Energy and its contractors, in paper, from:

U.S. Department of Energy

Office of Scientific and Technical Information

P.O. Box 62

Oak Ridge, TN 37831-0062

OSTI http://www.osti.gov

Phone: 865.576.8401

Fax: 865.576.5728

Email: reports@osti.gov

Available for sale to the public, in paper, from:

U.S. Department of Commerce

National Technical Information Service

5301 Shawnee Road

Alexandria, VA 22312

NTIS http://www.ntis.gov

Phone: 800.553 .6847 or 703.605 .6000

Fax: 703.605.6900

Email: orders@ntis.gov 


\section{Retrofitting Garden-Style Apartments in Brooklyn, New York}

Prepared for:

The National Renewable Energy Laboratory

On behalf of the U.S. Department of Energy's Building America Program

Office of Energy Efficiency and Renewable Energy

15013 Denver West Parkway

Golden, CO 80401

NREL Contract No. DE-AC36-08GO28308

Prepared by:

Heather Nolen, Sean Maxwell, Robin Neri, and Joanna Grab

Steven Winter Associates, Inc.

of the

Consortium for Advanced Residential Buildings (CARB)

61 Washington Street

Norwalk, CT 06854

NREL Technical Monitor: Chuck Booten

Prepared under Subcontract No. KNDJ-0-40342-05

February 2016 
The work presented in this report does not represent performance of any product relative to regulated minimum efficiency requirements.

The laboratory and/or field sites used for this work are not certified rating test facilities. The conditions and methods under which products were characterized for this work differ from standard rating conditions, as described.

Because the methods and conditions differ, the reported results are not comparable to rated product performance and should only be used to estimate performance under the measured conditions. 


\section{Contents}

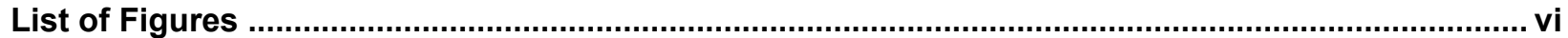

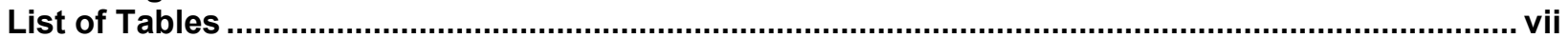

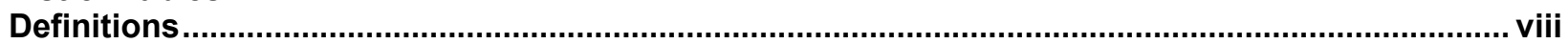

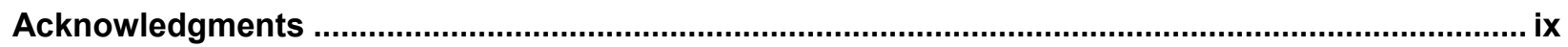

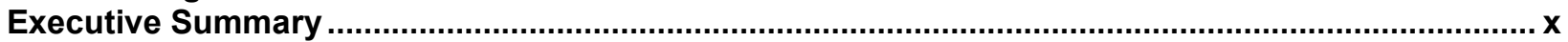

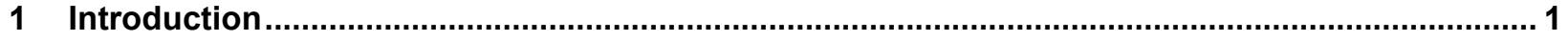

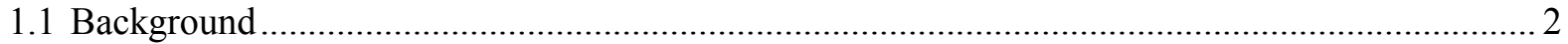

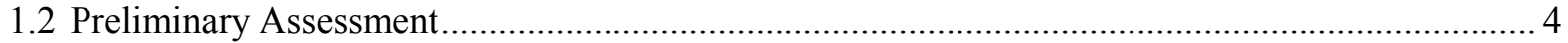

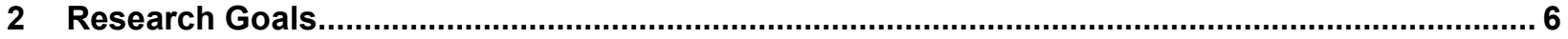

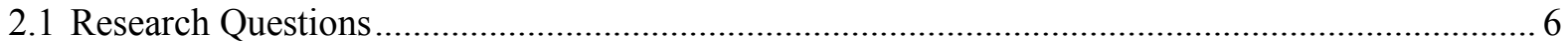

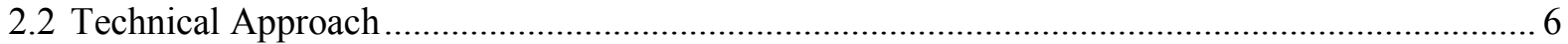

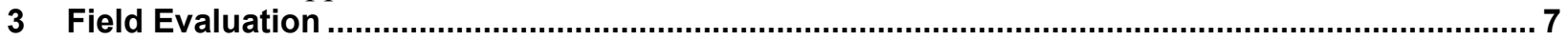

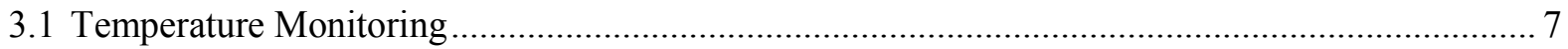

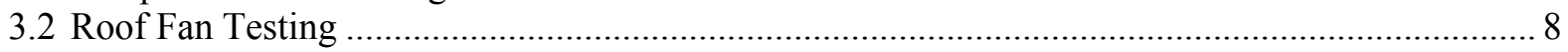

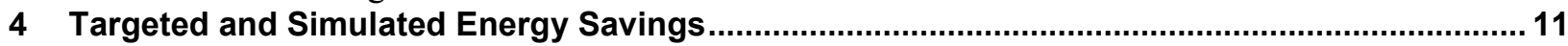

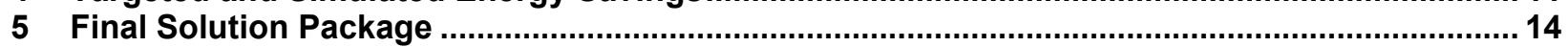

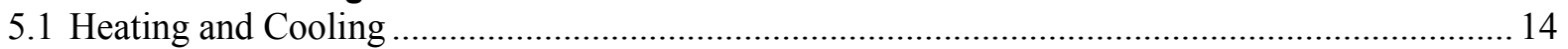

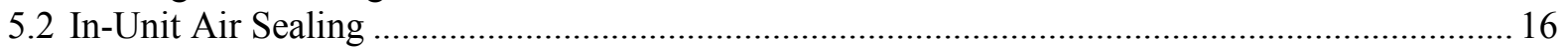

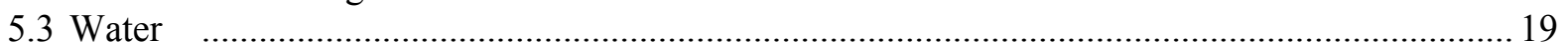

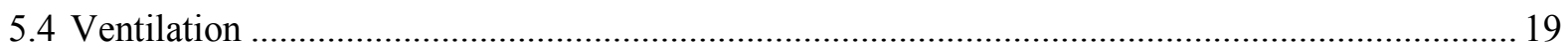

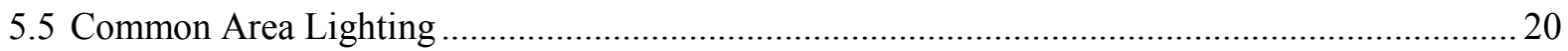

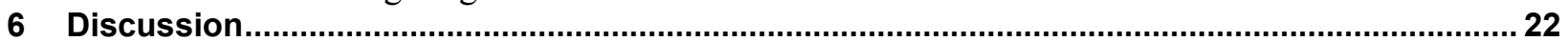

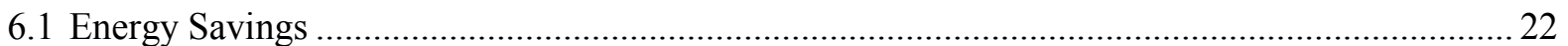

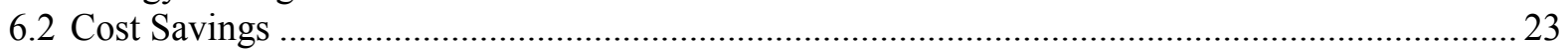

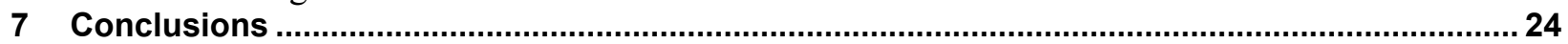

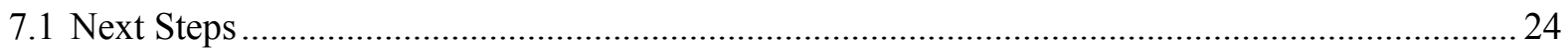

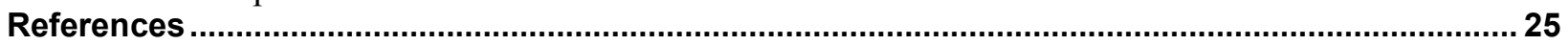




\section{List of Figures}

Figure 1. Street view of Marcus Garvey (left); terrace view of Marcus Garvey (right) ....................... 1

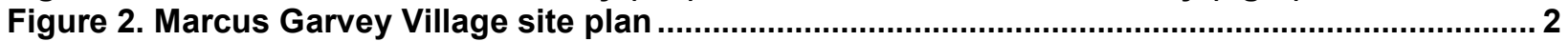

Figure 3. Daily electricity demand at Marcus Garvey Village .......................................................... 3

Figure 4. Marcus Garvey's utility cost breakdown by end use (weather-normalized)....................... 4

Figure 5. Average temperatures for occupied and unoccupied (vacant) apartments $( \pm 3$ standard deviations)

Figure 6. Existing in-unit bathroom exhaust ventilation registers ..................................................... 8

Figure 7. Inspection of roof-mounted exhaust fans (left); sheet metal ventilation shaft is located off-center from the roof fan curb (right)

Figure 8. Roof fan testing at Marcus Garvey: electrical measuring (left); airflow measuring (right). 8

Figure 9. Configuration of hybrid heat pump and electric baseboard controls ............................... 13

Figure 10. Existing in-unit positioning of the through-wall AC unit and electric baseboard............ 14

Figure 11. Existing in-unit electric baseboard controls .................................................................. 15

Figure 12. Newly installed oil-filled electric baseboard with control module (left end of

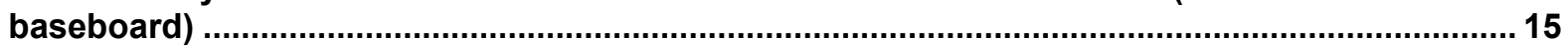

Figure 13. Sample dashboard view of in-unit temperatures and high temperature limits ................ 15

Figure 14. Original exterior wall insulation (left); newly applied rigid insulation over GWB and insulation (right)

Figure 15. Air-sealing strategy at wall AC sleeves

Figure 16. As-built observed conditions: A metal cover was installed in line with the exterior brick and caulked in place (left); batt insulation was placed inside the sleeve opening (right). 17

Figure 17. A metal cover was sealed to the sleeve opening (left), not shown is GWB covering the rigid insulation and sleeve cover; exterior louver (right)

Figure 18. Street view of through wall and window AC units (left); close-up view of through-wall and window AC units (right)

Figure 19. Mail slot at a courtyard-facing unit (left); new doors with wall-mounted mailboxes (right)

Figure 20.Typical in-unit plumbing penetration to be air sealed during bathroom upgrades .......... 19

Figure 21. DHW heaters (note that the flue vent pipes have insulation, which is a code violation and a fire hazard)

Figure 22. Scoop repair diagram: Scenario A shows how air can flow from one unit to another when the scoop is not positioned correctly. Scenario B shows how air from one unit cannot enter another unit when the scoop is positioned correctly.

Figure 23. Existing site lighting: pole lights, wall packs, and recessed lights............................... 20

Figure 24. Existing stairwell lighting (left); newly installed stairwell lighting after paint color was changed (right).

Figure 25. Sample in-unit bathroom lighting (left); replaced (right)

Unless otherwise noted, all figures were created by the CARB team. 


\section{List of Tables}

Table 1. Existing Specifications Summary.

Table 2. Existing Energy Use Breakdown by Fuel Type ............................................................... 3

Table 3. Preliminary Cost-Benefit Analysis for a Potential Heat Pump Retrofit................................. 5

Table 4. Roof Fan Testing Results and Comparison to Design Exhaust Flow .................................. 9

Table 5. Results of In-Unit Exhaust Flow Testing (Existing Conditions) .......................................... 10

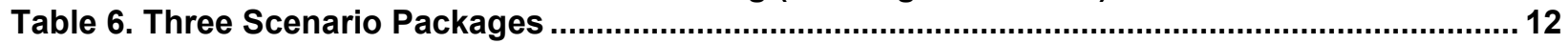

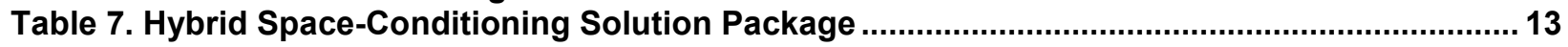

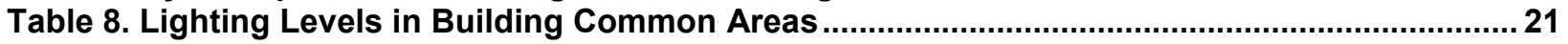

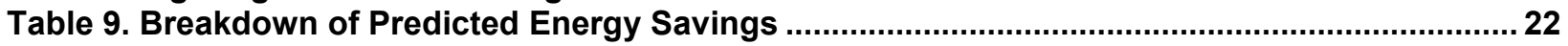

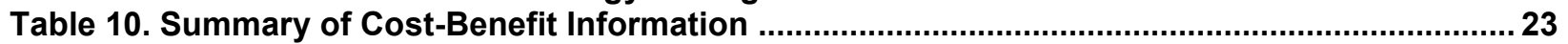

Unless otherwise noted, all tables were created by the CARB team. 


\section{Definitions}

$\mathrm{AC}$

CARB

CFM

DHW

GWB

LED

NYSERDA

SIR
Air conditioner

Consortium for Advanced Residential Buildings

Cubic Feet per Minute

Domestic Hot Water

Gypsum Wall Board

Light-Emitting Diode

New York State Energy and Research Development Authority

Savings-to-Investment Ratio 


\section{Acknowledgments}

This work was funded through the Building America Program of the U.S. Department of Energy Building Technologies Office. The authors are also grateful for the support and participation from L+M Development Partners, Inc. 


\section{Executive Summary}

This research effort sought to achieve a solution package that yields energy savings greater than $30 \%$ more than the existing conditions in a minimally intrusive, multifamily, retrofit project. The U.S. Department of Energy's Building America team Consortium for Advanced Residential Buildings partnered with L+M Development Partners, Inc., on a Mitchell-Lama Housing Program project, Marcus Garvey Village, in Brooklyn, New York (Climate Zone 4A). This program is a form of housing subsidy in the state of New York that provides affordable rental and cooperative housing to moderate- and middle-income families. Marcus Garvey Village was founded in 1975 and contains 625 residential units (ranging from studios to five-bedroom units) in 32 four-story garden-style apartment structures that were built with concrete and faced in light brown brick.

The single largest challenge to implementing energy-conservation measures at Marcus Garvey was working within occupied spaces. The building owner performed retrofit work on 40 units when they were unoccupied. All other units are being renovated while fully occupied. Residents are not being moved to different units to allow for construction in a vacant unit.

Measures are being implemented in phases to minimize disruption. As of August 2015, the retrofit work was more than 50\% complete. The wall insulation, sealing of the through-wall airconditioning vent, and installation of new, oil-filled, electric baseboards with advanced controls are being conducted simultaneously to limit disruption to the living room space. Similarly, the kitchen work is done first, then the bathroom. Cosmetic upgrades are also being made.

The final selection of energy-conservation measures is projected to save $26.5 \%$ in source energy. At a cost of about $\$ 3.7$ million and utility bill savings of nearly $\$ 480,000$ (of an average $\$ 1.8$ million annual utility cost for the development), this package was deemed cost-effective with a simple payback of 7.7 years.

The measure package implemented is very replicable, because it is practical for occupied apartments. The owners of this property feel comfortable with the scope of work they undertook and have already replicated some of the measures - specifically the electric baseboard controlsin other properties. They will continue to do so to realize additional benefits from the insulation retrofits that were already completed in these other properties. 


\section{Introduction}

The U.S. Department of Energy's Building America research team Consortium for Advanced Residential Buildings (CARB) partnered with L+M Development Partners, Inc., on a MitchellLama Housing Program project, Marcus Garvey Village, ${ }^{1}$ in Brooklyn, New York (Climate Zone 4A). This program is a form of housing subsidy in the state of New York that provides affordable rental and cooperative housing to moderate- and middle-income families. Marcus Garvey Village was founded in 1975 and is located in the Brownsville neighborhood of eastern Brooklyn. Its 625 garden-style apartment homes, within 32 buildings, range from studios to five-bedroom units. The garden walk-ups open into private courtyard areas.

Designed by architect Kenneth Frampton and the Institute for Architecture and Urban Studies, Marcus Garvey Village followed a "low-rise, high-density" prototype for families in need of housing, and most apartment homes incorporate in-block mews and private front doors (Figure 1).

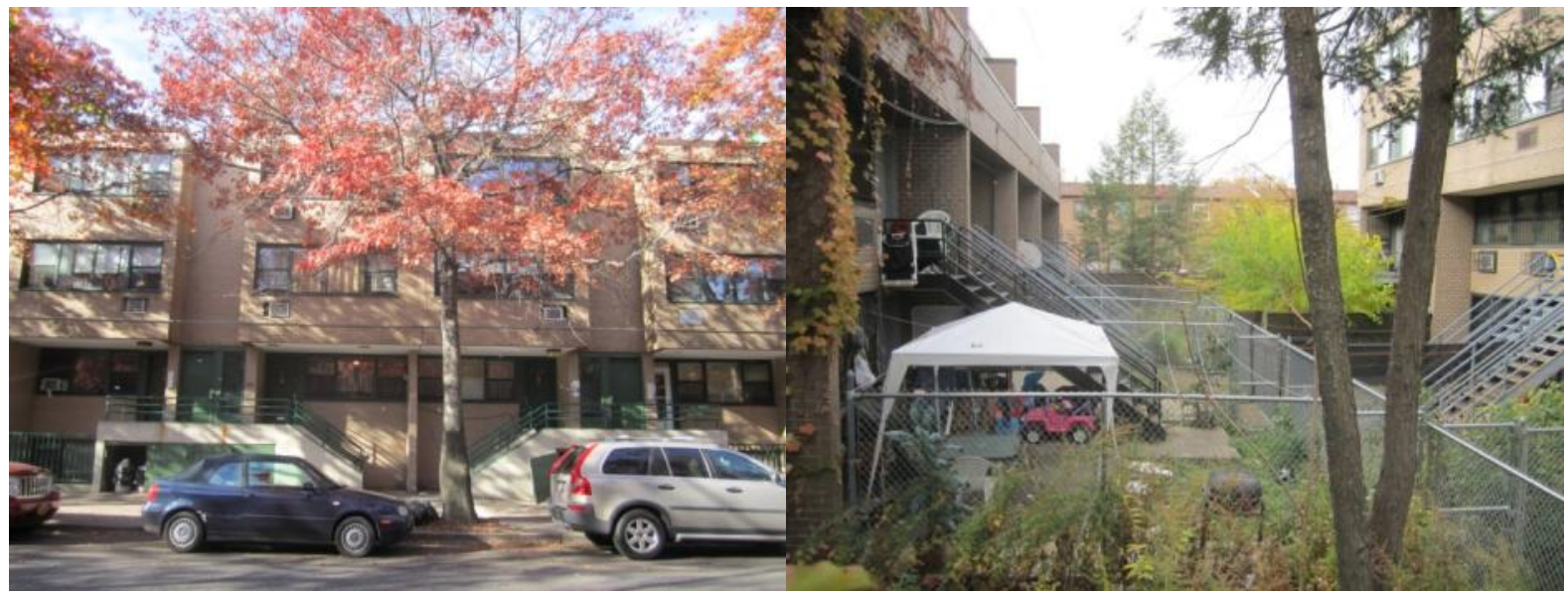

Figure 1. Street view of Marcus Garvey (left); terrace view of Marcus Garvey (right)

The project is laid out over seven contiguous blocks (Figure 2). It has seven boiler rooms, each of which serves the domestic hot water (DHW) needs of one block of apartments. Electricity is master-metered and handled by a single electricity meter on-site. The opportunity for electricity savings at this property is enormous, because electric resistance baseboards are used for space heating. Electric baseboards are simple systems; however, they are costly to operate. A summary of the various building components and existing specifications is provided in Table 1.

\footnotetext{
${ }^{1}$ www.marcusgarveyvillage.com/
} 


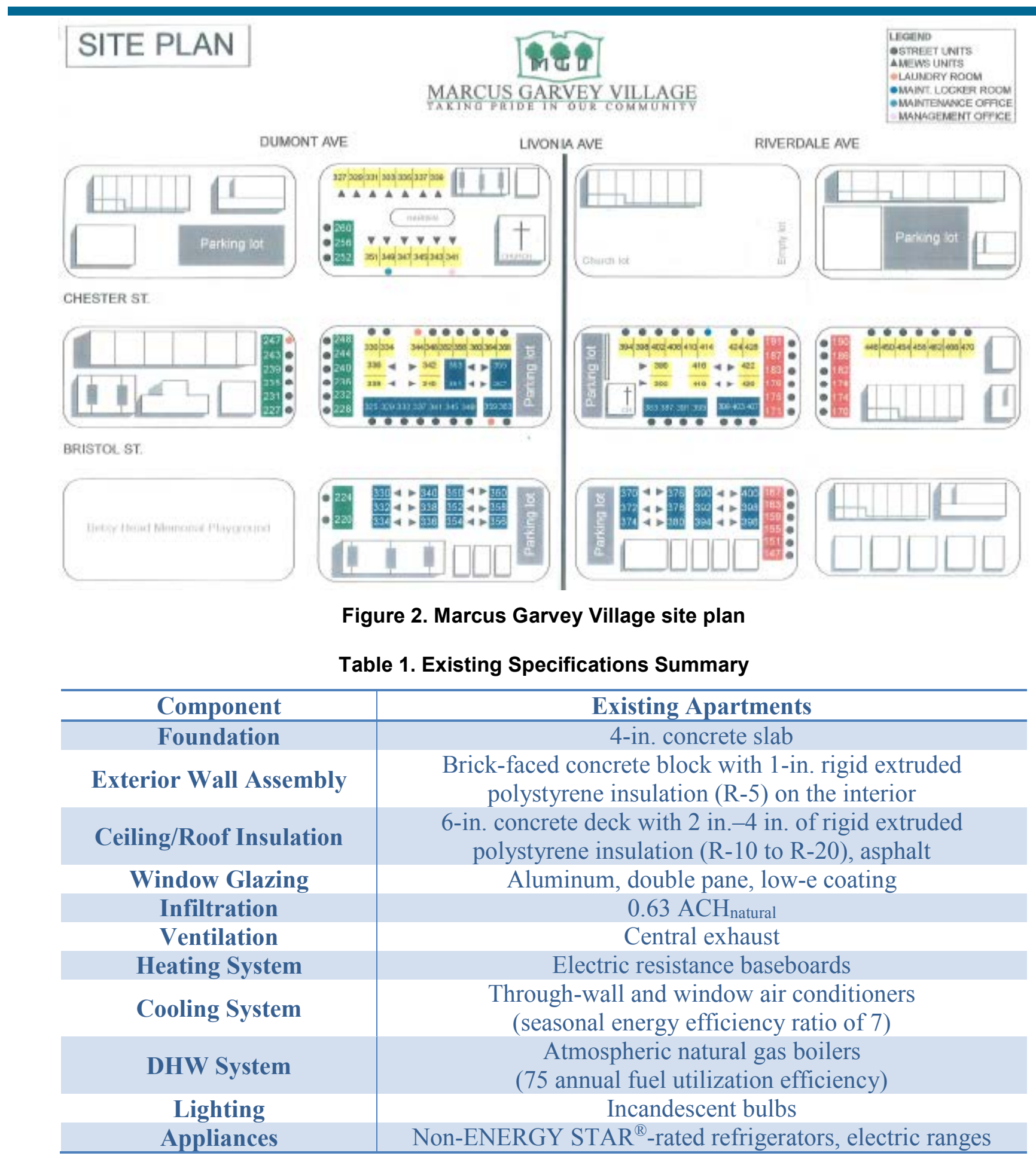

\subsection{Background}

Roughly $\$ 1.8$ million is spent annually on electricity and natural gas at Marcus Garvey Village (Table 2); the master-metered electricity bill comprises $90 \%$ of the total costs. With the highest cost per MBtu, electricity reductions were crucial to cost reductions. 
Table 2. Existing Energy Use Breakdown by Fuel Type

\begin{tabular}{c|c|c|c|c}
\hline \multirow{2}{*}{} & \multicolumn{2}{|c|}{ Most Recent Year (2012) } & \multicolumn{2}{c}{$\begin{array}{c}\text { Weather-Normalized } \\
\text { (Based on 2003-2012) }\end{array}$} \\
\cline { 2 - 5 } & Consumption & Cost $^{\mathrm{a}}$ & Consumption $^{\text {Cost }^{\text {a }}}$ \\
\hline Electricity (kWh) & $9,640,000$ & $\$ 1,735,056$ & $10,406,000$ & $\$ 1,873,000$ \\
Natural Gas (Therm) & 247,000 & $\$ 202,300$ & 246,000 & $\$ 201,500$ \\
Total Costs & & $\$ 1,937,356$ & & $\$ 2,074,500$ \\
\hline
\end{tabular}

${ }^{a}$ An average blended electricity rate of $\$ 0.18 / \mathrm{kWh}$ and natural gas rate of $\$ 0.82 /$ therm were based on developerprovided energy bills and used in all the analyses.

Electricity demand, which is an indicator of energy use intensity in multifamily buildings, was extremely high in the winter months (Figure 3) at the Marcus Garvey Village development. Through utility bill disaggregation methods, CARB was able to confirm that electricity use for winter heating is the largest fraction of utility bills (Figure 4). Therefore, due to the high electricity demand and a desire to maintain affordable housing, the developer sought costeffective solutions to reduce annual utility bills. The developer is participating in the New York State Energy Research and Development Authority's (NYSERDA's) Multifamily Performance Program, which provides per-unit incentives with the potential for an additional performance payment. NYSERDA's base energy savings is $15 \%$, and to be eligible for performance payments properties must save more than $20 \% .^{2}$ With projected savings of $26.5 \%$, the project is eligible for $\$ 500,000$ in total incentives from NYSERDA. The performance payment (included in the $\$ 500,000$ total) would be awarded 1 year post construction, based on actual energy bills.

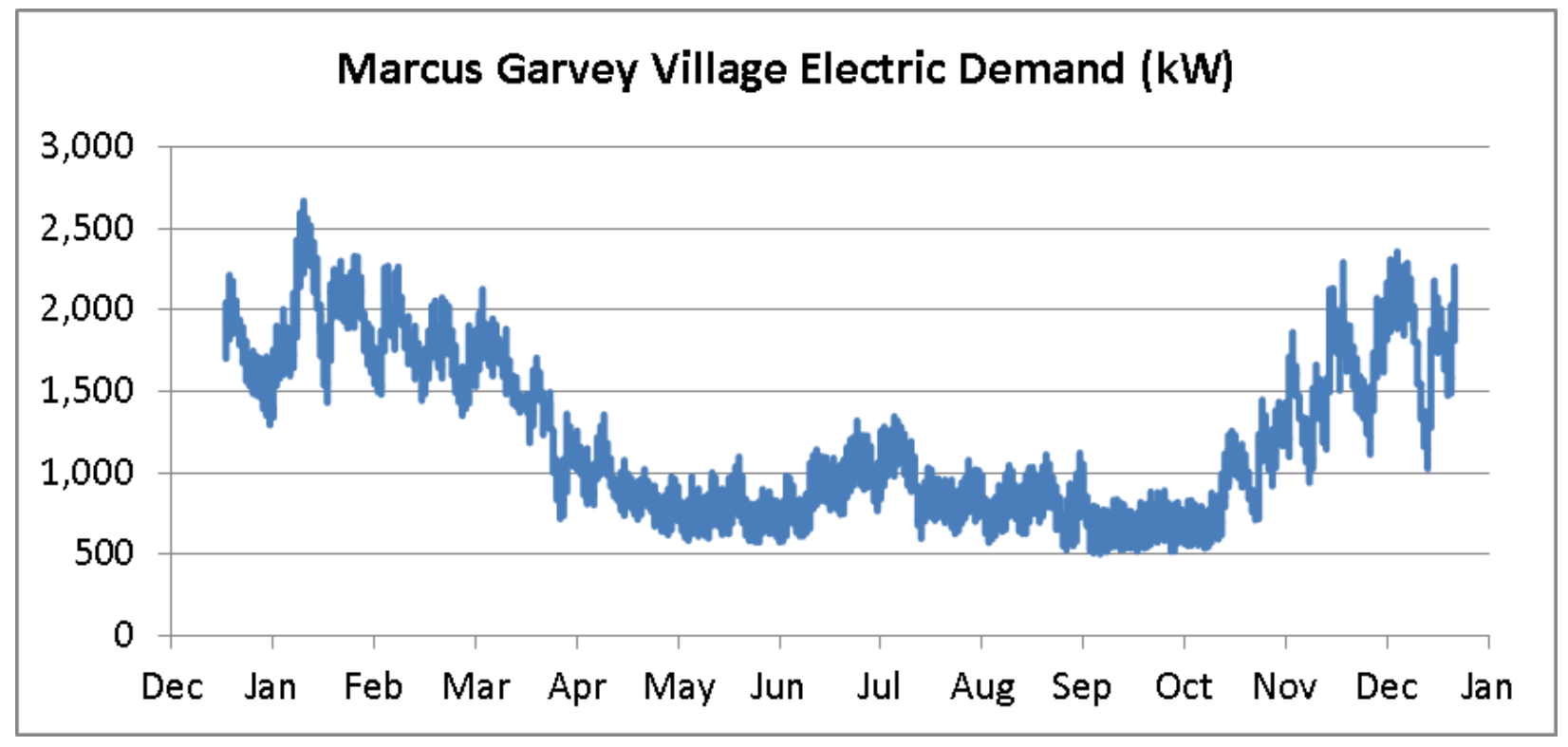

Figure 3. Daily electricity demand at Marcus Garvey Village

\footnotetext{
${ }^{2}$ www.nyserda.ny.gov/Energy-Efficiency-and-Renewable-Programs/Multifamily-Performance-Program/Multifamily$\underline{\text { Performance-Program/Existing-Buildings.aspx }}$
} 


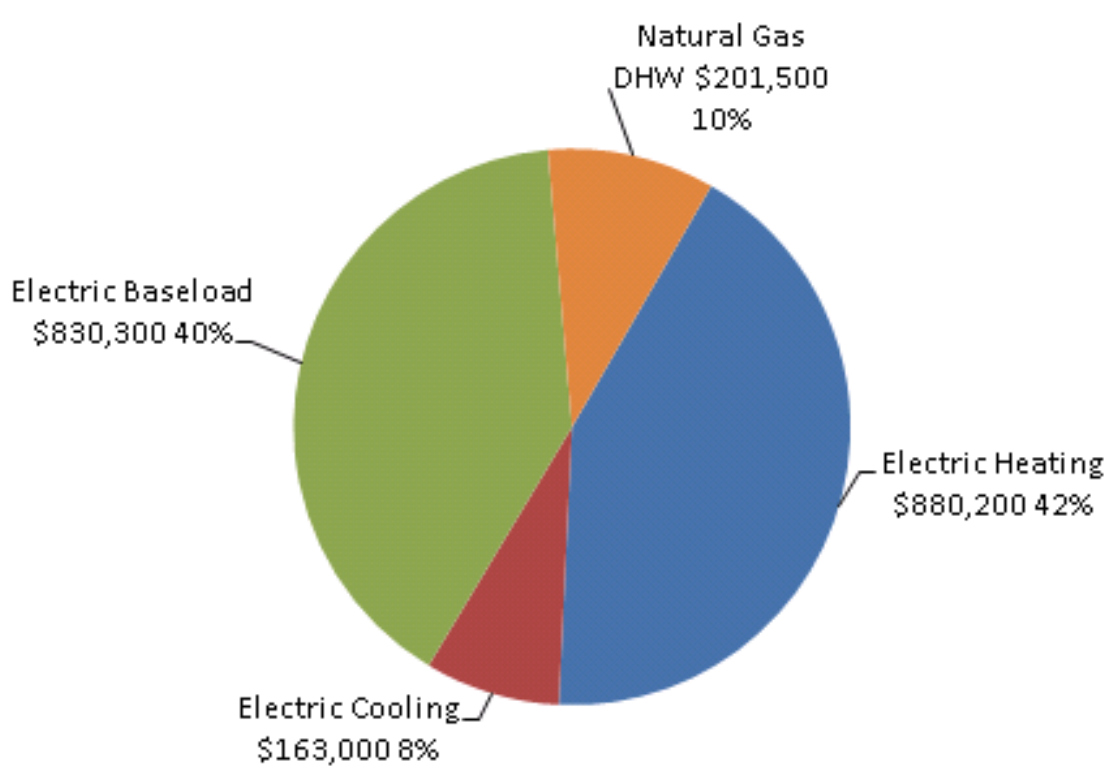

Figure 4. Marcus Garvey's utility cost breakdown by end use (weather-normalized)

\subsection{Preliminary Assessment}

During initial walk-throughs, the CARB team identified the potential to convert the property from electric resistance heat to electric heat pumps as one of the most impactful possibilities for this project. Technology advancements have made heat pumps an extremely effective replacement for many types of heating systems. Efficiency Maine, which has installed more than 3,000 heat pumps over the past few years, has found that units installed through its program have resulted in more than $50 \%$ energy savings over existing heating systems and resulted in some of the lowest operating costs of any system it has analyzed. ${ }^{3}$

CARB conducted preliminary analyses using the Targeted Retrofit Energy Analysis Tool energy-modeling software to assess the savings potential for conversion to heat pump systems. Initially developed in conjunction with National Renewable Energy Laboratory engineers and funded by NYSERDA, the Targeted Retrofit Energy Analysis Tool is commonly used to qualify buildings for NYSERDA financial incentives. This initial analysis indicated that converting the main heating and cooling systems from electric baseboards and sleeve air conditioners (ACs) to inverter-driven heat pumps could save as much as $27 \%$ on electricity costs.

The cost of the heat pump retrofit was estimated at $\$ 8,000$ per apartment, or about $\$ 5$ million for the entire development. With $\$ 510,000$ per year in potential utility cost savings (Table 3 ), the simple payback of this single measure would be about 10 years (approximately 8 years with possible incentives). This improvement alone could bring many benefits for managers and residents, and significant cost savings could result.

\footnotetext{
${ }^{3}$ www.efficiencymaine.com/docs/EMT_Energy-Efficient-Heating-Options-Report_2013_4_8.pdf
} 
Table 3. Preliminary Cost-Benefit Analysis for a Potential Heat Pump Retrofit

\begin{tabular}{c|c|c|c}
\cline { 2 - 3 } & $\begin{array}{c}\text { Possible } \\
\text { Funds } \\
\text { Available }\end{array}$ & Unit & $\begin{array}{c}\text { Whole } \\
\text { Project }\end{array}$ \\
\hline $\begin{array}{c}\text { Cost of Heat Pump Retrofit } \\
\text { NYSERDA Multifamily Performance } \\
\text { Program }\end{array}$ & $\$ 8,000$ & Per unit & $\$ 5,000,000$ \\
\hline $\begin{array}{c}\text { NYSERDA Multifamily Performance } \\
\text { Program Performance Payment }\end{array}$ & $\$ 200$ & Per unit & $\$ 375,000$ \\
\hline $\begin{array}{c}\text { Total Cost } \\
\text { Energy Savings }\end{array}$ & Per unit & $\$ 125,000$ \\
\hline $\begin{array}{c}\text { Simpler 1 year } \\
\text { Simple Payback (Without Incentives) }\end{array}$ & & & $\$ 4,500,000$ \\
\hline
\end{tabular}

Additional measures that were identified during the initial walk-throughs included:

- As an alternative to heat pumps, update the electric resistance baseboards to oil-filled electric resistance baseboards and provide some type of tenant and master control. (Currently the tenants control these.)

- One block of apartments could be renovated to have hydronic baseboards served by a central boiler.

- The AC units are tenant owned, so many are low efficiency and fit poorly within the through-wall AC sleeve, which causes air leakage. Switching the ownership of the AC units to the building owners was evaluated. If this is done, the AC units would be updated, and tenant controls would be incorporated.

- Air sealing focused on accessible envelope penetrations and the AC sleeves.

- The exterior walls had 1 in. of rigid insulation on the interior side that was fairly broken up due to wiring and other penetrations. Possibly fix or patch the insulation, and add an additional $1 \mathrm{in}$. of rigid insulation on the interior side of the exterior walls.

- Install light-emitting diode (LED) fixtures in common areas and outdoors, and upgrade apartment lighting to compact fluorescent lamps.

- Update all the refrigerators to ENERGY STAR models.

- Install low-flow plumbing fixtures and aerators.

- Seal and balance the central ventilation system.

- Upgrade the central DHW systems from atmospheric natural gas boilers to direct-vent boilers. 


\section{Research Goals}

\subsection{Research Questions}

The intent of this research effort was to answer the following questions:

- What are potential solution packages to achieve $30 \%$ source energy savings over existing conditions in these concrete garden-style apartments faced in brick?

- What is the maximum cost-effectiveness of the solution package for achieving $30 \%$ source energy savings?

- How effectively can this solution package be replicated in other climate zone 4A apartment buildings?

\subsection{Technical Approach}

CARB visited the property to collect information about its conditions and then performed modeling studies to identify several measure packages to achieve $30 \%$ source energy savings. CARB worked with the project team to seek building system solutions that would optimize energy efficiency (based on energy models), comfort (based on pre- and post-temperature and relative humidity monitoring in a sample of units), maintenance ease (based on feedback from maintenance staff), and cost (based on estimates from the builder partner). Initial evaluations focused on the following:

- Ways to improve the exterior wall assemblies (insulation and air sealing). Exterior applied insulating solutions were not practical because the owners wanted to retain the brick façade and the costs of a new façade were too high. Therefore, insulation strategies for the interior of the wall assembly were evaluated.

- Ways to improve compartmentalization (minimizing transfer of air) between dwelling units

- Ways to improve efficiencies of:

○ Space-conditioning equipment

○ Water-heating equipment

○ Ventilation equipment.

Once optimal solution packages were identified, CARB worked with the project team to determine which energy-conservation measures would be pursued and to address issues and concerns that arose during the decision-making process. 


\section{Field Evaluation}

More than 30 resident units were tested and inspected; the following information was measured and collected:

- Indoor temperature

- DHW temperature at the faucet

- Water flow at the kitchen and bath faucets and the showerhead

- Lighting type and quantity

- Bathroom exhaust ventilation flow (cubic feet per minute [CFM]) and static pressure.

Common area and property-wide equipment was also tested and inspected including:

- Stairwell lighting levels

- DHW equipment efficiency

- Total exhaust flow from the fans at the roof level.

\subsection{Temperature Monitoring}

Data loggers were deployed for 2 weeks in March 2014 to gather indoor unit temperatures. Temperature data were gathered to analyze occupied, unoccupied, and vacant apartment temperatures (Figure 5). Interviews with residents revealed that individual apartment electric baseboard heating controls were often broken or simply not used. This caused occupied units to be overheated by roughly $5^{\circ} \mathrm{F}$ or more from the desired set point temperatures $\left(68^{\circ}-70^{\circ} \mathrm{F}\right)$. In many instances, occupants opened windows to cool the units. The data also indicate the potential for savings from the use of master controls in vacant units, to adjust the unoccupied set point to minimize energy consumption and still maintain the required temperatures to avoid freezing. A similar process of data logging will be conducted post construction for measurement and verification and commissioning of the controls.

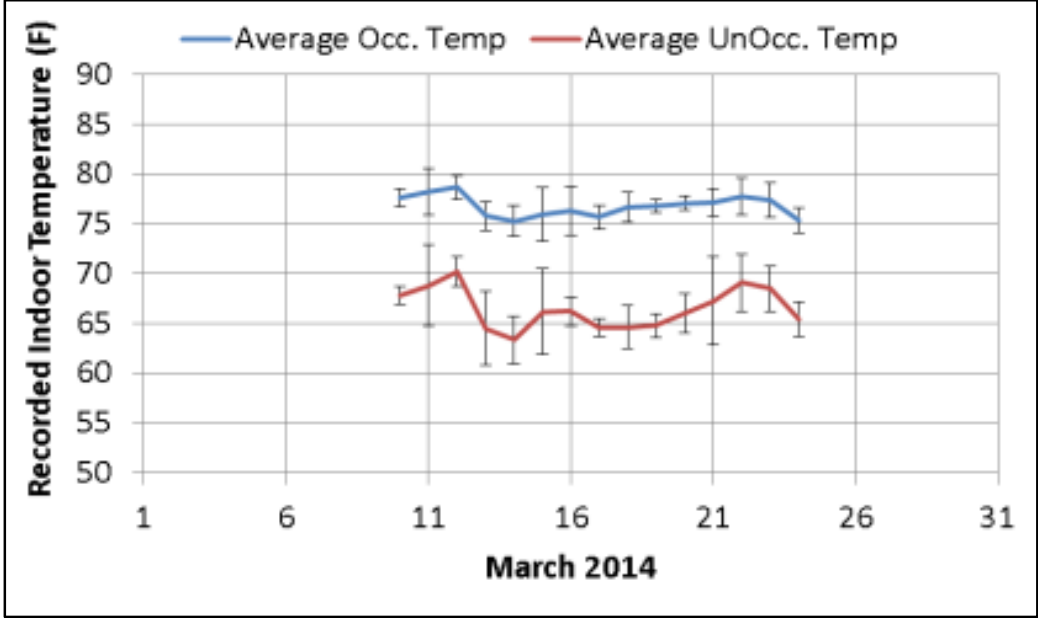

Figure 5. Average temperatures for occupied and unoccupied (vacant) apartments $( \pm 3$ standard deviations) 


\subsection{Roof Fan Testing}

The residential units have mechanically exhausted bathrooms that are served by roof-mounted fans. Two to six bathroom exhaust outlets are typically joined to a central duct that terminates at the roof fan. In many of the bathrooms the outlet register has been taped over, which effectively eliminates any exhaust from that room (Figure 6). The CARB team examined the roof fans to determine their conditions (Figure 7) and conducted testing at 14 roof fans to measure airflow (Figure 8).

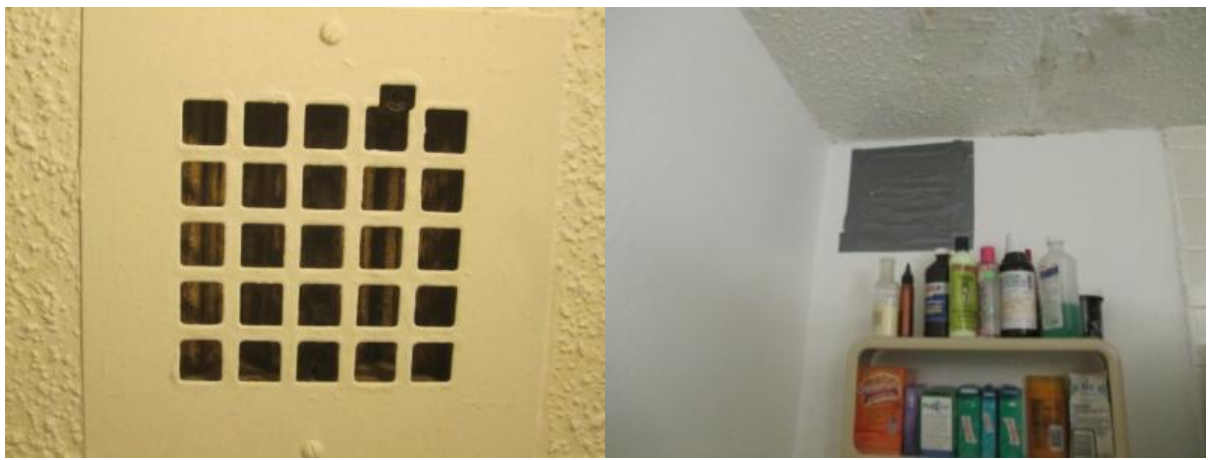

Figure 6. Existing in-unit bathroom exhaust ventilation registers

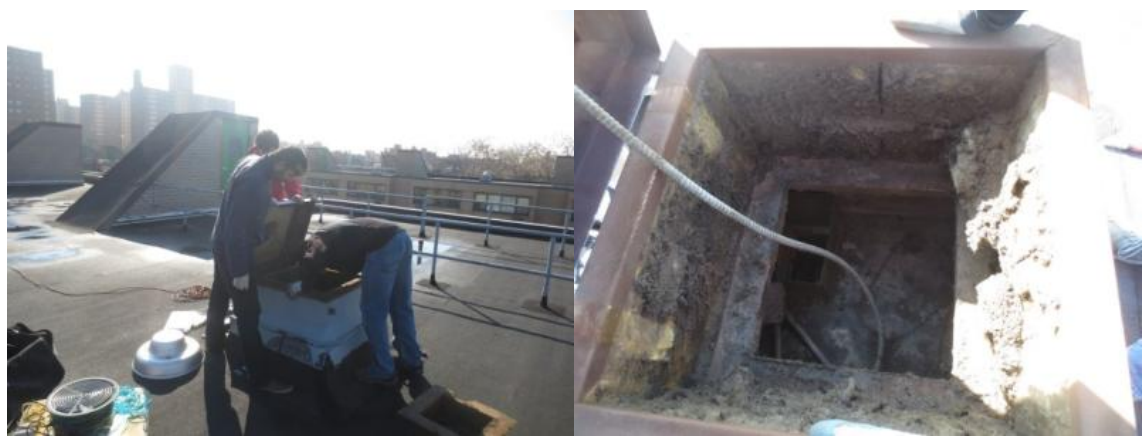

Figure 7. Inspection of roof-mounted exhaust fans (left); sheet metal ventilation shaft is located off-center from the roof fan curb (right)

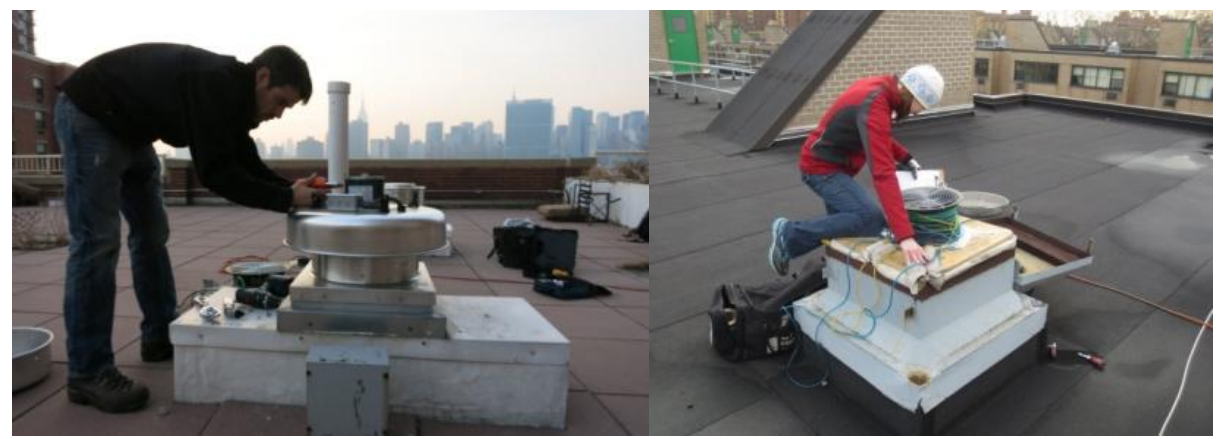

Figure 8. Roof fan testing at Marcus Garvey: electrical measuring (left); airflow measuring (right) 
Results of the roof fan exhaust flow testing (Table 4) indicated that seven of the fan units were significantly overexhausting and one fan unit was significantly underexhausting. However, despite overventilation measurements for the majority of the fan units at the roof level, the inunit testing of exhaust registers (Table 5) indicated that $80 \%$ of the units had little to no exhaust flow. Some residents reported air flowing into their units rather than exhausting. They thus covered the exhaust registers to reduce infiltration. The results of these tests suggest that air was being pulled from spaces other than the in-unit exhausts registers.

Table 4. Roof Fan Testing Results and Comparison to Design Exhaust Flow

\begin{tabular}{|c|c|c|c|c|c}
\hline Building & $\begin{array}{c}\text { Tested Flow } \\
\text { (CFM) }\end{array}$ & $\begin{array}{c}\text { \# Baths } \\
\text { Served }\end{array}$ & $\begin{array}{c}\text { Design Flow } \\
\text { (CFM) }\end{array}$ & $\begin{array}{c}\text { CFM } \\
\text { Difference }\end{array}$ & $\begin{array}{c}\text { \% } \\
\text { Difference }^{\text {CFM }}\end{array}$ \\
\hline $\mathbf{2 4 7}$ & 118 & 2 & 60 & 58 & $97 \%$ \\
$\mathbf{2 4 7}$ & Off & 3 & 90 & N/A & N/A \\
$\mathbf{2 4 3}$ & 223 & 2 & 60 & 163 & $272 \%$ \\
$\mathbf{2 3 9}$ & 203 & 6 & 180 & 23 & $13 \%$ \\
$\mathbf{2 3 5}$ & 170 & 6 & 180 & -10 & $-6 \%$ \\
$\mathbf{2 3 1}$ & 242 & 6 & 180 & 62 & $34 \%$ \\
$\mathbf{2 2 7}$ & 249 & 3 & 90 & 159 & $177 \%$ \\
$\mathbf{3 6 8}$ & 260 & 3 & 90 & 170 & $189 \%$ \\
$\mathbf{3 6 4}$ & 170 & 6 & 180 & -10 & $-6 \%$ \\
$\mathbf{3 6 0}$ & 170 & 5 & 150 & 20 & $13 \%$ \\
$\mathbf{3 6 0}$ & 272 & 6 & 180 & 92 & $51 \%$ \\
$\mathbf{3 5 6}$ & 390 & 6 & 180 & 210 & $117 \%$ \\
$\mathbf{3 5 2}$ & 102 & 6 & 180 & -78 & $-43 \%$ \\
$\mathbf{3 4 8}$ & 109 & 3 & 90 & 19 & $21 \%$ \\
$\mathbf{3 4 4}$ & 74 & 2 & 60 & 14 & $23 \%$ \\
\hline
\end{tabular}

${ }^{a}$ Green shaded cells indicate overventilation, orange indicates underventilation. 
Table 5. Results of In-Unit Exhaust Flow Testing (Existing Conditions)

\begin{tabular}{|c|c|c|c|c|c|c|c|c|c|}
\hline Location/Apartment Number & 224D & 224B & $220 \mathrm{~A}$ & 239E & 231F & 341C & 364E & 343B & 333E \\
\hline \multirow{2}{*}{$\begin{array}{l}\text { Bath Exhaust CFM } \\
\text { Bath Exhaust Static Pressure }\end{array}$} & a & a & $\mathrm{N} / \mathrm{A}$ & $\mathrm{a}$ & a & $\mathrm{N} / \mathrm{A}$ & $\mathrm{a}$ & $\mathrm{a}$ & $\mathrm{a}$ \\
\hline & -0.6 & -1.3 & $\mathrm{~N} / \mathrm{A}$ & 0.6 & -0.1 & N/A & -0.2 & -0.8 & 0.7 \\
\hline Location/Apartment Number & $155 \mathrm{C}$ & 147A & 239C & 252A & 231E & 383A & 348A & 376A & $364 \mathrm{C}$ \\
\hline \multirow{2}{*}{$\begin{array}{l}\text { Bath Exhaust CFM } \\
\text { Bath Exhaust Static Pressure }\end{array}$} & a & 17 & a & 8 & 0 & 12 & 0 & 0 & 0 \\
\hline & -4.7 & -0.8 & -0.5 & -1.5 & 0 & -4 & 0 & 0 & -1.4 \\
\hline Location/Apartment Number & 348E & $446 C$ & 424D & $182 \mathrm{~A}$ & 428A & & $256 \mathrm{E}$ & $224 A$ & 343D \\
\hline \multirow{2}{*}{$\begin{array}{l}\text { Bath Exhaust CFM } \\
\text { Bath Exhaust Static Pressure }\end{array}$} & $*$ & $\mathrm{~N} / \mathrm{A}$ & $*$ & 16 & 16 & 10 & 0 & $\mathrm{~N} / \mathrm{A}$ & $*$ \\
\hline & -1.6 & N/A & -2.8 & -5.3 & -6.5 & -2.8 & -6 & N/A & -0.4 \\
\hline Location/Apartment Number & 332D & 368A & 333A & $364 A$ & 329F & 335C & 331C & 325A & $183 C$ \\
\hline \multirow{2}{*}{$\begin{array}{c}\text { Bath Exhaust CFM } \\
\text { Bath Exhaust Static Pressure }\end{array}$} & N/A & 15 & $\mathrm{~b}$ & $\mathrm{a}$ & 0 & 0 & 0 & 0 & $\mathrm{~b}$ \\
\hline & N/A & N/A & N/A & -3.5 & 0 & 0 & -1.9 & -1.2 & N/A \\
\hline
\end{tabular}

${ }^{a}$ Below the measurement range of the test equipment; negligible exhaust flow.

${ }^{\mathrm{b}}$ Exhaust grille was covered or taped over. 


\section{Targeted and Simulated Energy Savings}

After the additional verification and field testing, a more comprehensive energy modeling compared to the initial walk-through analysis (Section 1.2) was completed. Again using Targeted Retrofit Energy Analysis Tool Version 3.0 software, the team calculated the cost and savings for three space-conditioning solution packages. Additional measures related to lighting, appliances, DHW, low-flow fixtures, wall insulation, and air sealing were kept constant in each scenario.

- Scenario 1: Complete conversion of the entire complex to hydronic heat

- Scenario 2: Complete conversion to heat pumps

- Scenario 3: Implementation of baseboard heat controls across the whole complex.

This side-by-side arrangement in Table 6 offers a way to compare the relative cost-effectiveness of various measures under each scenario. The total source energy savings as a percent is listed on the "All Measures" line at the bottom of the table, along with annual utility cost savings and capital costs (estimates provided by building partner).

The team ruled out the hydronic conversion because the cost of implementing a conversion to hydronic baseboards throughout the development was too high. The developer indicated that additional costs for gas infrastructure were not accounted for in the cost estimate, so the cost estimates were too optimistic. The oil-filled baseboards and temperature controls conversion was considered the minimum level of efficiency that would be pursued. Still, the project team was quite interested in the heat pump conversion. However, the capital expenditures and recurring maintenance costs required to implement this strategy across the entire development and the building maintenance staff's lack of familiarity and comfort with the technology were causes for concern. Therefore, an alternative hybrid strategy (Figure 9) that combined the use of heat pumps for the main living area (due to the open concept of the living room and kitchen) and electric baseboard control improvements in the individual bedrooms was evaluated. Table 7 illustrates what would happen to annual cost and energy savings if this hybrid solution were implemented across the development. 
Table 6. Three Scenario Packages

\begin{tabular}{|c|c|c|c|c|c|c|c|c|c|c|}
\hline \multirow{2}{*}{\multicolumn{2}{|c|}{ Measure Name }} & \multicolumn{3}{|c|}{ Hydronic Conversion } & \multicolumn{3}{|c|}{ Heat Pump Conversion } & \multicolumn{3}{|c|}{$\begin{array}{c}\text { Oil-Filled Baseboards and } \\
\text { Temperature Controls } \\
\text { Conversion } \\
\end{array}$} \\
\hline & & \multirow{2}{*}{$\begin{array}{c}\text { Cost } \\
\$ 8,180,000\end{array}$} & \multirow{2}{*}{$\begin{array}{c}\begin{array}{c}\text { Annual } \\
\text { Cost } \\
\text { Savings }^{\mathbf{a}}\end{array} \\
\$ 600,000\end{array}$} & \multirow{2}{*}{ 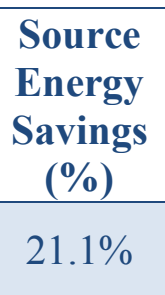 } & \multirow{2}{*}{$\begin{array}{c}\text { Cost } \\
\$ 5,702,000\end{array}$} & \multirow{2}{*}{$\begin{array}{c}\begin{array}{c}\text { Annual } \\
\text { Cost } \\
\text { Savings }\end{array} \\
\$ 440,000\end{array}$} & \multirow{2}{*}{$\begin{array}{c}\begin{array}{c}\text { Source } \\
\text { Energy } \\
\text { Savings } \\
(\%)\end{array} \\
20.3 \% \\
\end{array}$} & \multirow{2}{*}{$\begin{array}{c}\text { Cost } \\
\$ 786,000\end{array}$} & \multirow{2}{*}{$\begin{array}{c}\begin{array}{c}\text { Annual } \\
\text { Cost } \\
\text { Savings }\end{array} \\
\$ 240,000\end{array}$} & \multirow{2}{*}{$\begin{array}{c}\begin{array}{c}\text { Source } \\
\text { Energy } \\
\text { Savings } \\
(\%)\end{array} \\
11 \%\end{array}$} \\
\hline 1 & $\begin{array}{l}\text { Heating system } \\
\text { change }\end{array}$ & & & & & & & & & \\
\hline 2 & $\begin{array}{c}\text { New DHW } \\
\text { boilers }\end{array}$ & $\$ 1,000,000$ & $\$ 51,000$ & $5.2 \%$ & $\$ 1,000,000$ & $\$ 51,000$ & $5.2 \%$ & $\$ 1,000,000$ & $\$ 51,000$ & $5.2 \%$ \\
\hline 3 & $\begin{array}{l}\text { Install rigid } \\
\text { insulation }\end{array}$ & $\$ 944,000$ & $\$ 73,000$ & $3.4 \%$ & $\$ 940,000$ & $\$ 73,000$ & $3.4 \%$ & $\$ 944,000$ & $\$ 73,000$ & $3.4 \%$ \\
\hline 4 & $\begin{array}{c}\text { Unit-low-flow } \\
\text { aerators }\end{array}$ & $\$ 31,500$ & $\$ 29,000$ & $2.9 \%$ & $\$ 31,000$ & $\$ 29,000$ & $2.9 \%$ & $\$ 31,500$ & $\$ 29,000$ & $2.9 \%$ \\
\hline 5 & $\begin{array}{c}\text { New } \\
\text { refrigerators }\end{array}$ & $\$ 283,000$ & $\$ 36,000$ & $1.7 \%$ & $\$ 283,000$ & $\$ 36,000$ & $1.7 \%$ & $\$ 283,000$ & $\$ 36,000$ & $1.7 \%$ \\
\hline 6 & Air sealing & $\$ 380,000$ & $\$ 31,000$ & $1.4 \%$ & $\$ 380,000$ & $\$ 31,000$ & $1.4 \%$ & $\$ 380,000$ & $\$ 31,000$ & $1.4 \%$ \\
\hline 7 & $\begin{array}{l}\text { Apartment } \\
\text { lighting }\end{array}$ & $\$ 203,000$ & $\$ 12,000$ & $0.6 \%$ & $\$ 203,000$ & $\$ 12,000$ & $0.6 \%$ & $\$ 203,000$ & $\$ 12,000$ & $0.6 \%$ \\
\hline \multirow[t]{3}{*}{8} & $\begin{array}{c}\text { Exterior lighting } \\
\text { upgrade }\end{array}$ & $\$ 60,000$ & $\$ 7,600$ & $0.3 \%$ & $\$ 60,000$ & $\$ 7,600$ & $0.3 \%$ & $\$ 60,000$ & $\$ 7,600$ & $0.3 \%$ \\
\hline & All measures & $\$ 11,081,500$ & $\$ 839,600$ & $36.5 \%$ & $\$ 8,599,000$ & $\$ 679,600$ & $35.7 \%$ & $\$ 3,687,500$ & $\$ 479,600$ & $26.5 \%$ \\
\hline & Payback (years) & & & 13.2 & & & 12.7 & & & 7.7 \\
\hline
\end{tabular}

${ }^{a}$ Cost savings are based on developer-provided energy bills, and an average blended electricity rate of $\$ 0.18 / \mathrm{kwh}$ and natural gas rate of $\$ 0.82 /$ therm were used in all analyses. 


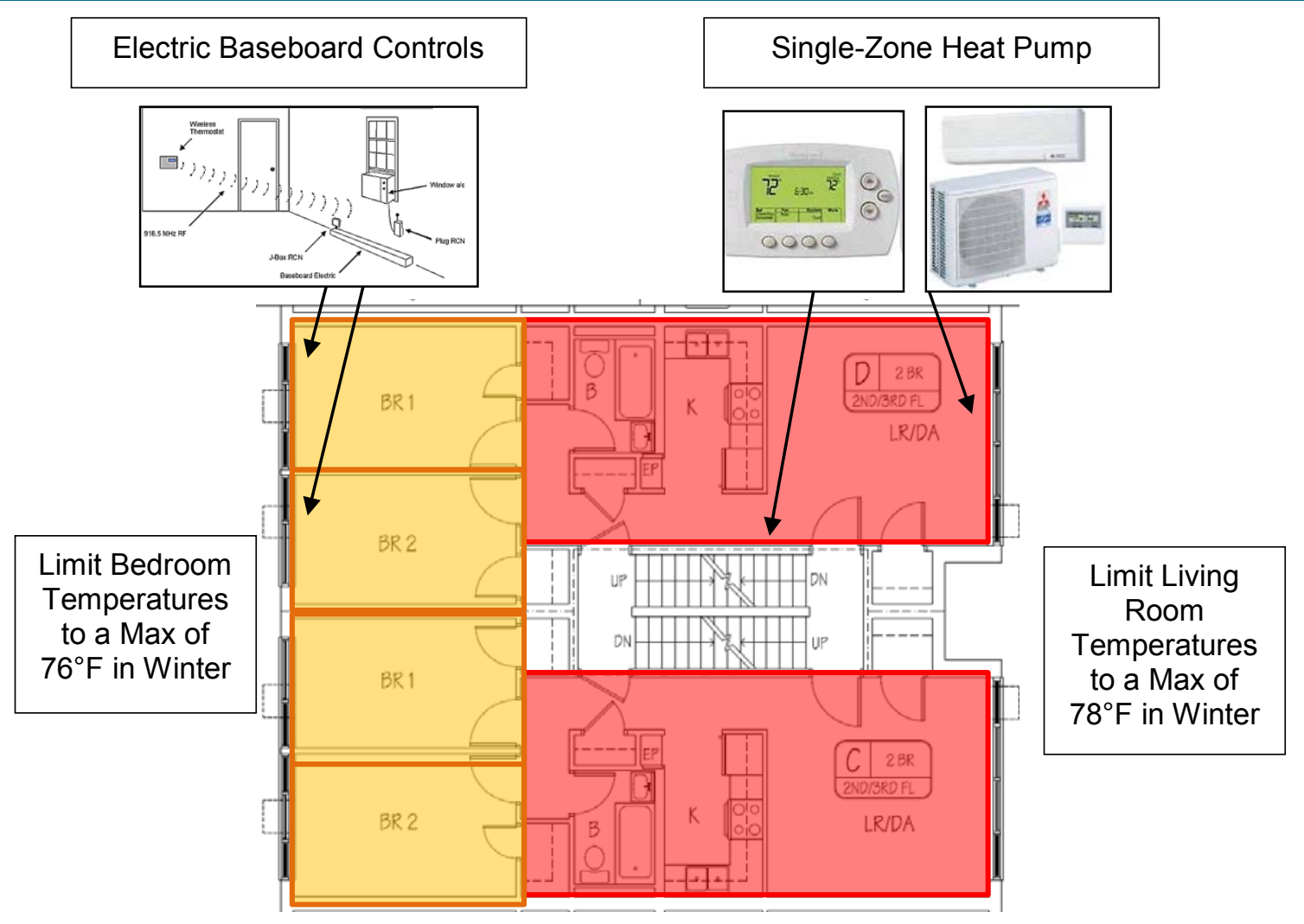

Figure 9. Configuration of hybrid heat pump and electric baseboard controls

Table 7. Hybrid Space-Conditioning Solution Package

Hybrid Heat Pump and Oil-Filled Baseboards and Temperature Controls Conversion

\begin{tabular}{|c|c|c|c|c|}
\hline \multicolumn{2}{|c|}{ Measure Name } & \multirow{2}{*}{$\begin{array}{c}\text { Cost } \\
\$ 5,024,200\end{array}$} & \multirow{2}{*}{$\begin{array}{c}\begin{array}{c}\text { Annual Cost } \\
\text { Savings }\end{array} \\
\$ 386,700\end{array}$} & \multirow{2}{*}{$\begin{array}{c}\begin{array}{c}\text { Source Energy } \\
\text { Savings } \\
(\%)\end{array} \\
16.3 \%\end{array}$} \\
\hline 1 & Heating system change & & & \\
\hline 2 & New DHW boilers & $\$ 1,000,000$ & $\$ 51,000$ & $5.2 \%$ \\
\hline 3 & Install rigid insulation & $\$ 944,000$ & $\$ 73,000$ & $3.4 \%$ \\
\hline 4 & Unit-low-flow aerators & $\$ 31,500$ & $\$ 29,000$ & $2.9 \%$ \\
\hline 5 & New refrigerators & $\$ 283,000$ & $\$ 36,000$ & $1.7 \%$ \\
\hline 6 & Air sealing & $\$ 380,000$ & $\$ 31,000$ & $1.4 \%$ \\
\hline 7 & Apartment lighting & $\$ 203,000$ & $\$ 12,000$ & $0.6 \%$ \\
\hline \multirow[t]{3}{*}{8} & Exterior lighting upgrade & $\$ 60,000$ & $\$ 7,600$ & $0.3 \%$ \\
\hline & All measures & $\$ 7,925,700$ & $\$ 626,300$ & $31.8 \%$ \\
\hline & Payback (years) & & & 12.7 \\
\hline
\end{tabular}




\section{Final Solution Package}

After thoroughly reviewing the options for improving the efficiency of heating and cooling equipment, the owner selected new oil-filled electric baseboards and temperature-limiting thermostats with master and tenant controls. Equipment familiarity, durability, and capital cost influenced the decision to retain electric resistance heating rather than installing heat pumps. The seven base package measures were implemented as well.

The final solution package selected achieves a less significant energy savings than other options; however, it provides a considerable improvement over existing conditions. As is often the case in retrofit projects, initial capital requirements and consideration for occupant interactions influence the decision-making process. Still, the scale of this development makes the overall energy reductions significant.

\subsection{Heating and Cooling}

The heating and cooling system was in need of updating. ACs were tenant provided, and often window air ACs were installed in the through-wall sleeve (Figure 10). Neither window nor insleeve ACs were well air sealed, and they invited air leakage. Where through-wall sleeves were not used, a plate was simply installed over the exterior gap, leaving an uninsulated cavity behind it. Baseboard heaters had dial controls (Figure 11). These could easily be left on even during the summer, especially if furniture blocked the controls, and easily forgotten. These issues with the through-wall sleeves and the dial controls provided great opportunities for energy savings.

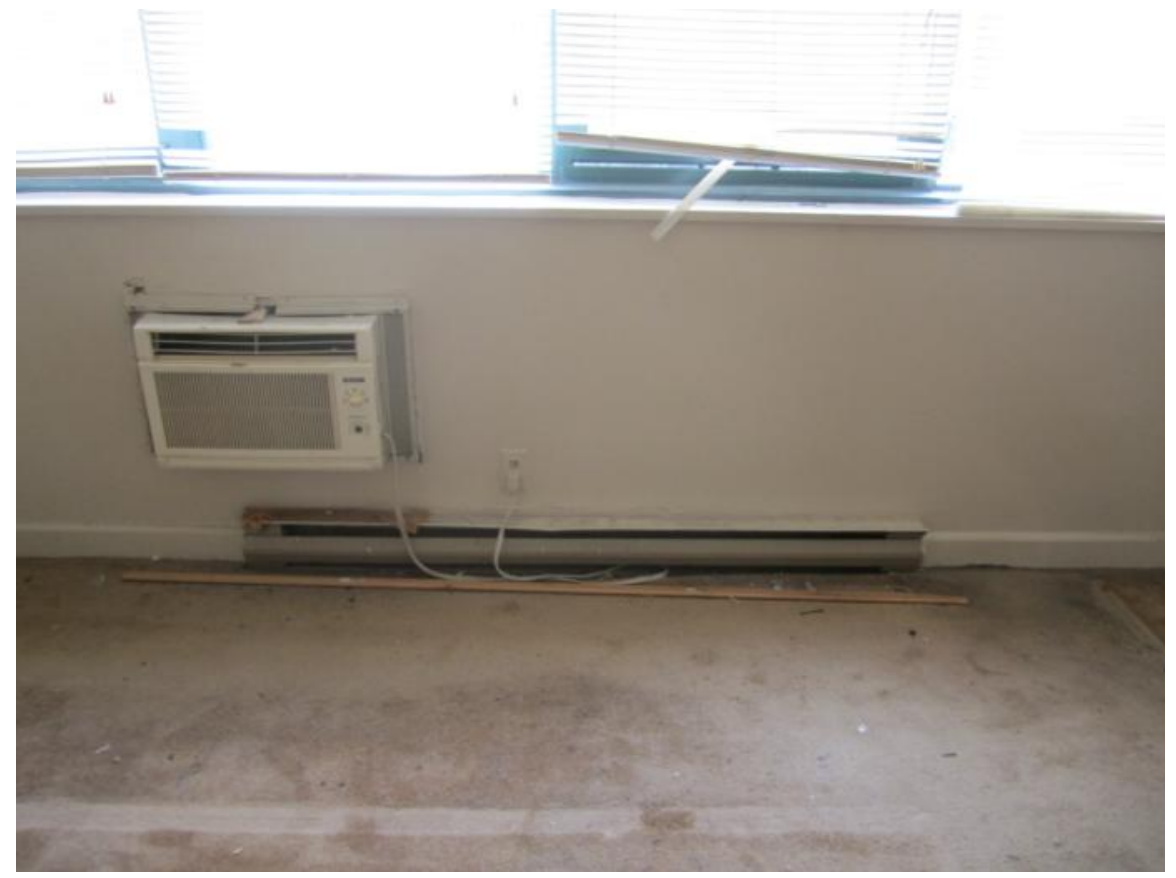

Figure 10. Existing in-unit positioning of the through-wall $A C$ unit and electric baseboard 


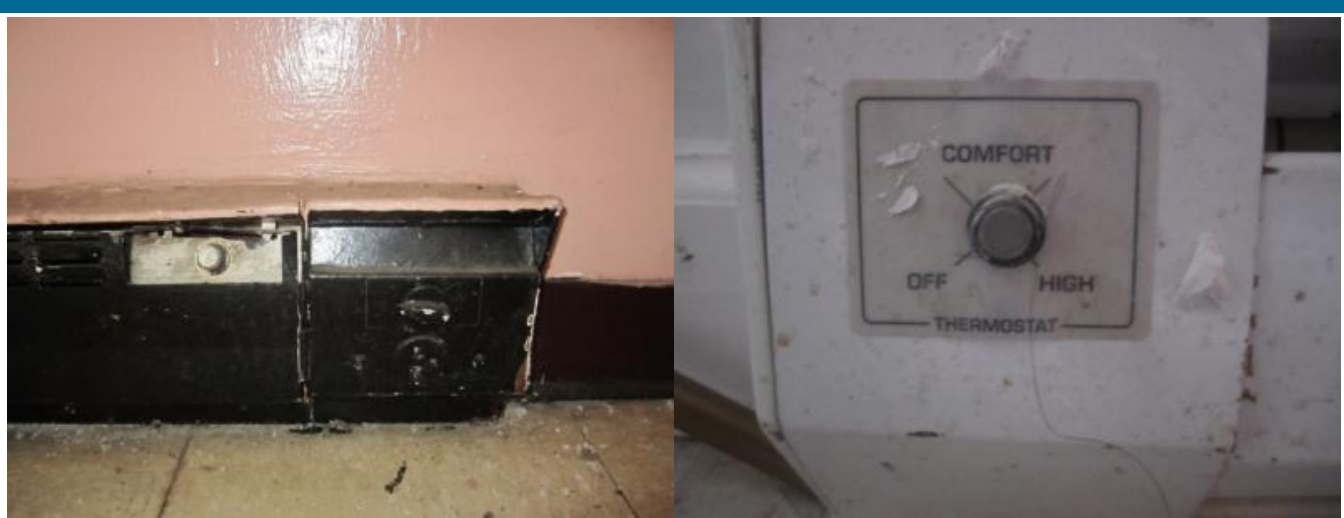

Figure 11. Existing in-unit electric baseboard controls

The new temperature-limiting thermostats that were selected for the retrofit communicate wirelessly to a relay that is mounted to the baseboard heaters (Figure 12). These thermostats and controls can be used for nighttime setback and have a warm weather shutdown feature to eliminate unnecessary heating during warm periods (Figure 13).

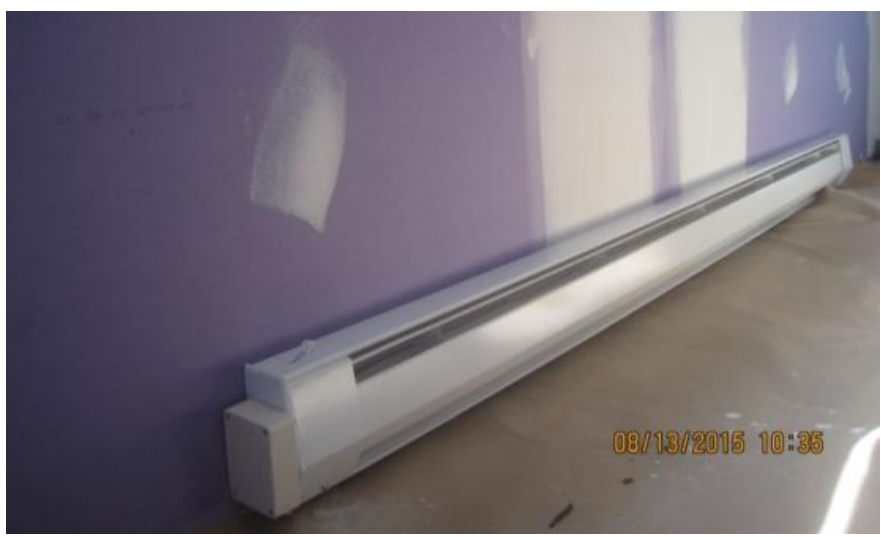

Figure 12. Newly installed oil-filled electric baseboard with control module (left end of baseboard)

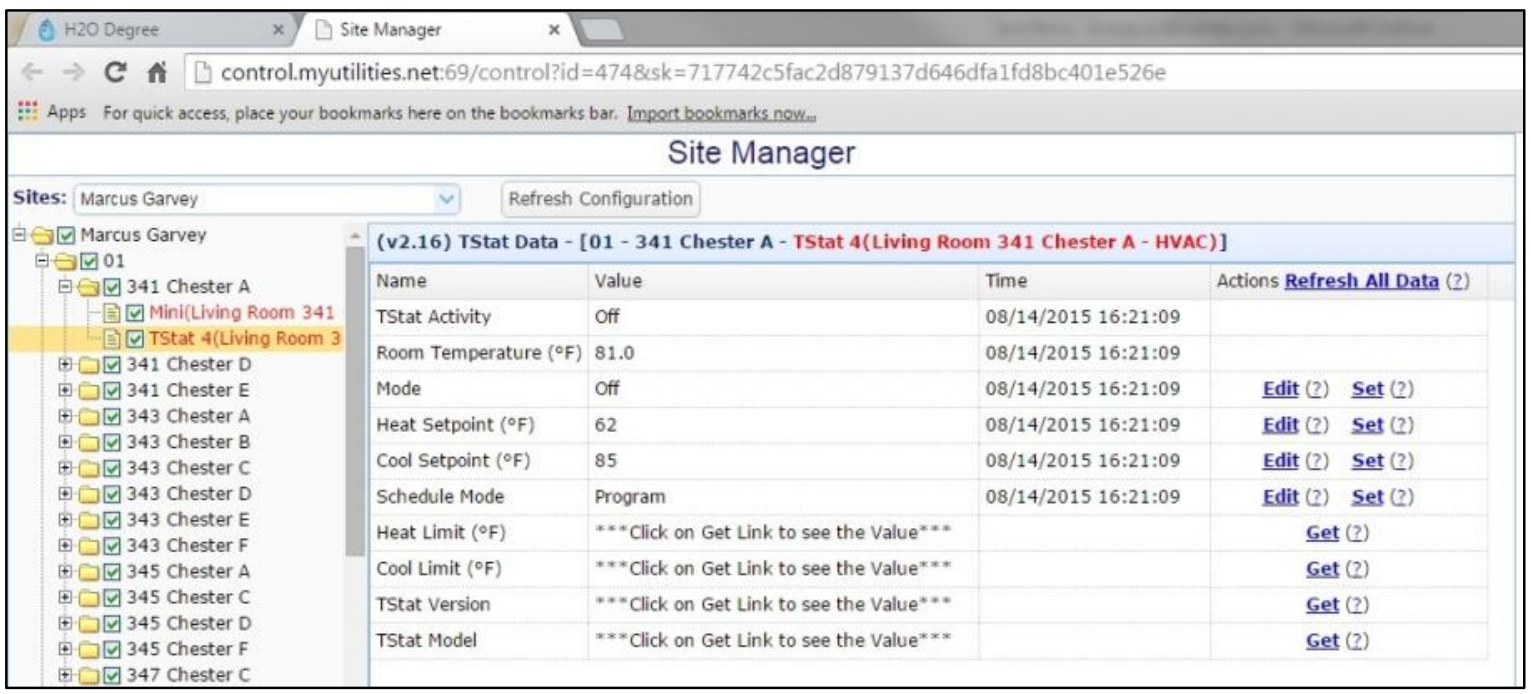

Figure 13. Sample dashboard view of in-unit temperatures and high temperature limits 


\subsection{In-Unit Air Sealing}

The property had $1 \mathrm{in}$. of rigid insulation under the gypsum wall board (GWB) on the interior face of the block. It was in poor condition, because it was improperly installed and wiring was routed through the insulation (Figure 14). To improve the thermal performance of the exterior walls, an additional inch of extruded polystyrene rigid insulation was installed over the GWB and another layer of GWB was applied over the new rigid insulation (the wall was studded out with steel framing). This continuous surface was a straightforward method to reduce wall penetrations for energy savings in a retrofit.
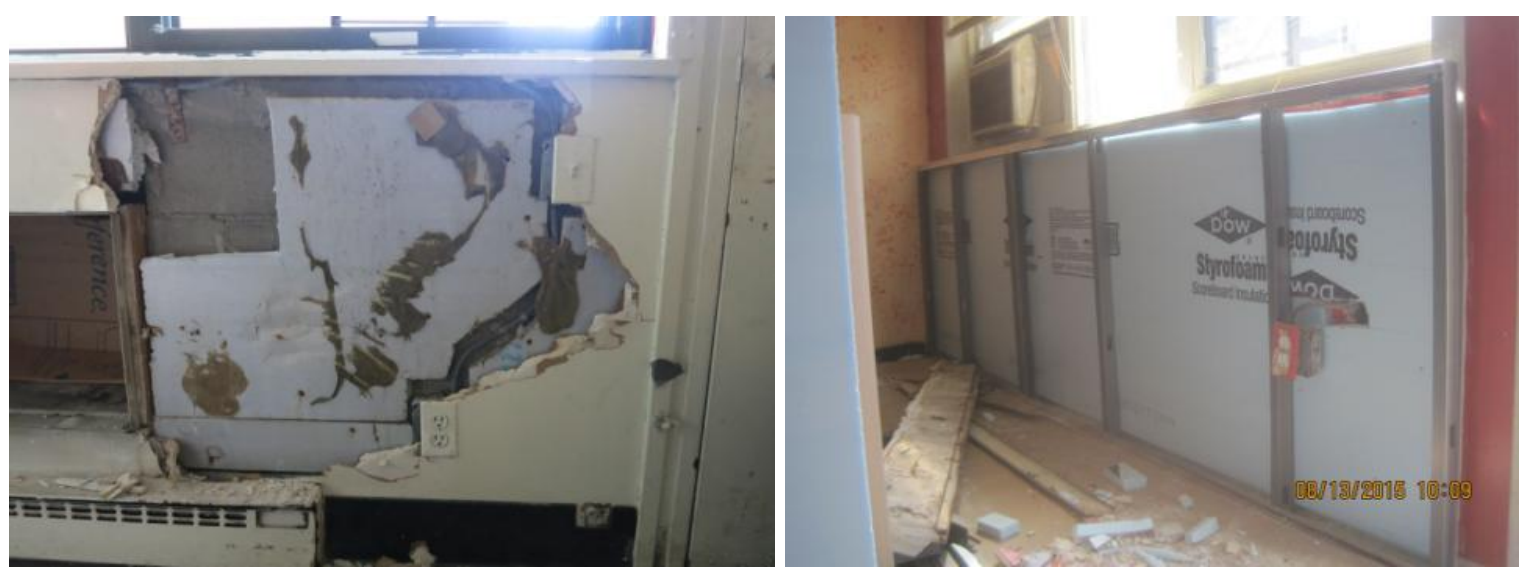

Figure 14. Original exterior wall insulation (left); newly applied rigid insulation over GWB and insulation (right)

The living rooms have sleeves for through-wall AC units. The recommended retrofit scope included blocking the wall sleeve penetration with a combination of insulation and an exterior weather barrier (Figure 15). Air sealing was done to reduce infiltration. The interior wall received new GWB over the opening to eliminate future use of the through-wall AC sleeve. Therefore, tenants can now use only window AC units for cooling.

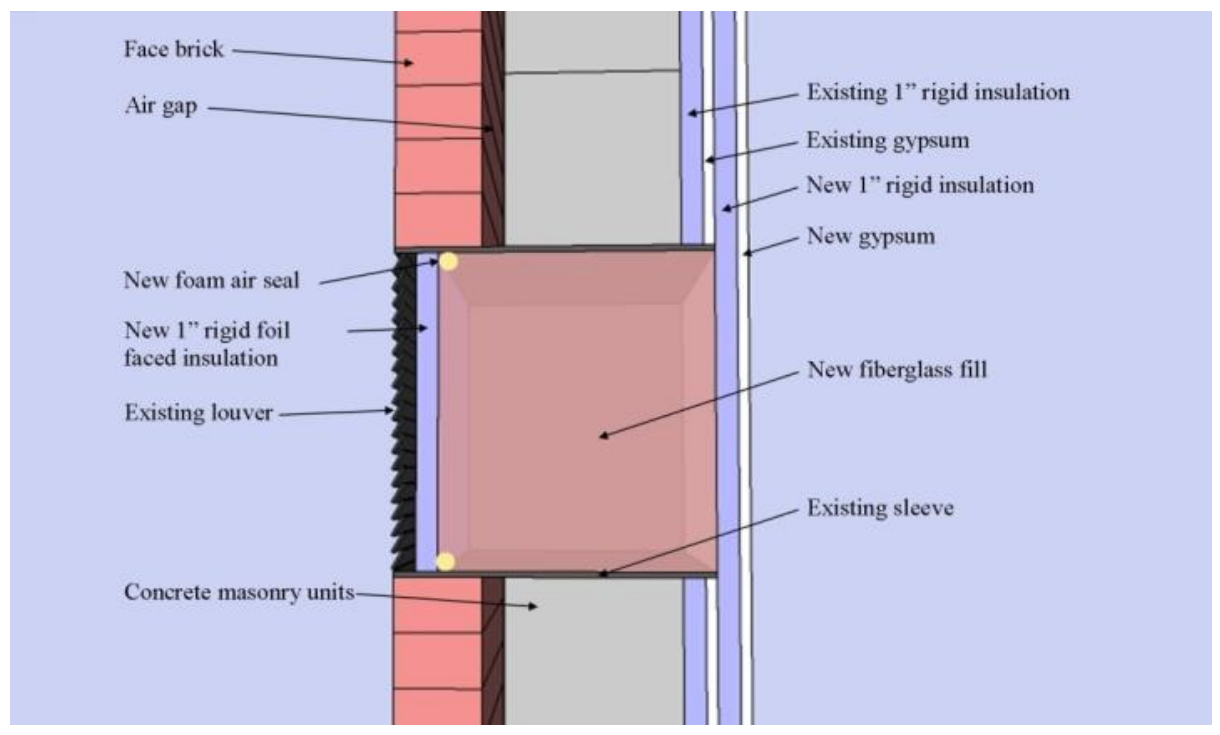

Figure 15. Air-sealing strategy at wall AC sleeves 
The actual detail of the sleeve removal (Figure 16 and Figure 17) varied from the initial design (Figure 15). The team noted that rigid insulation could not be carried continuously across the sleeve opening on the interior face of the wall. The sleeve space protruded into the room, which prevented the rigid insulation from being installed over the sleeve. The architect and the construction team sealed the opening, which consists of a metal plate at the brick face, with caulking. Batt insulation was fit to the space in the opening. The opening was then covered with a second metal plate and sealed in place. GWB was then run over the rigid insulation (surrounding the sleeve) and the metal plate (which was over the sleeve opening).

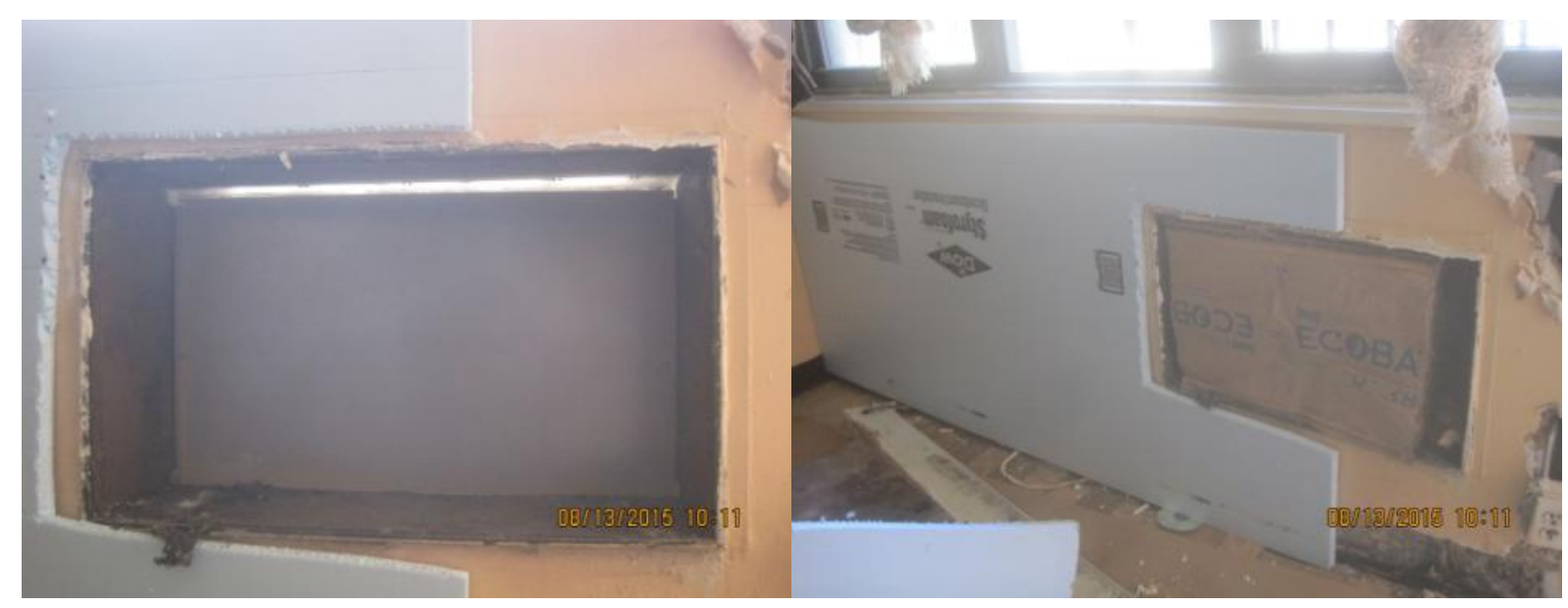

Figure 16. As-built observed conditions: A metal cover was installed in line with the exterior brick and caulked in place (left); batt insulation was placed inside the sleeve opening (right).
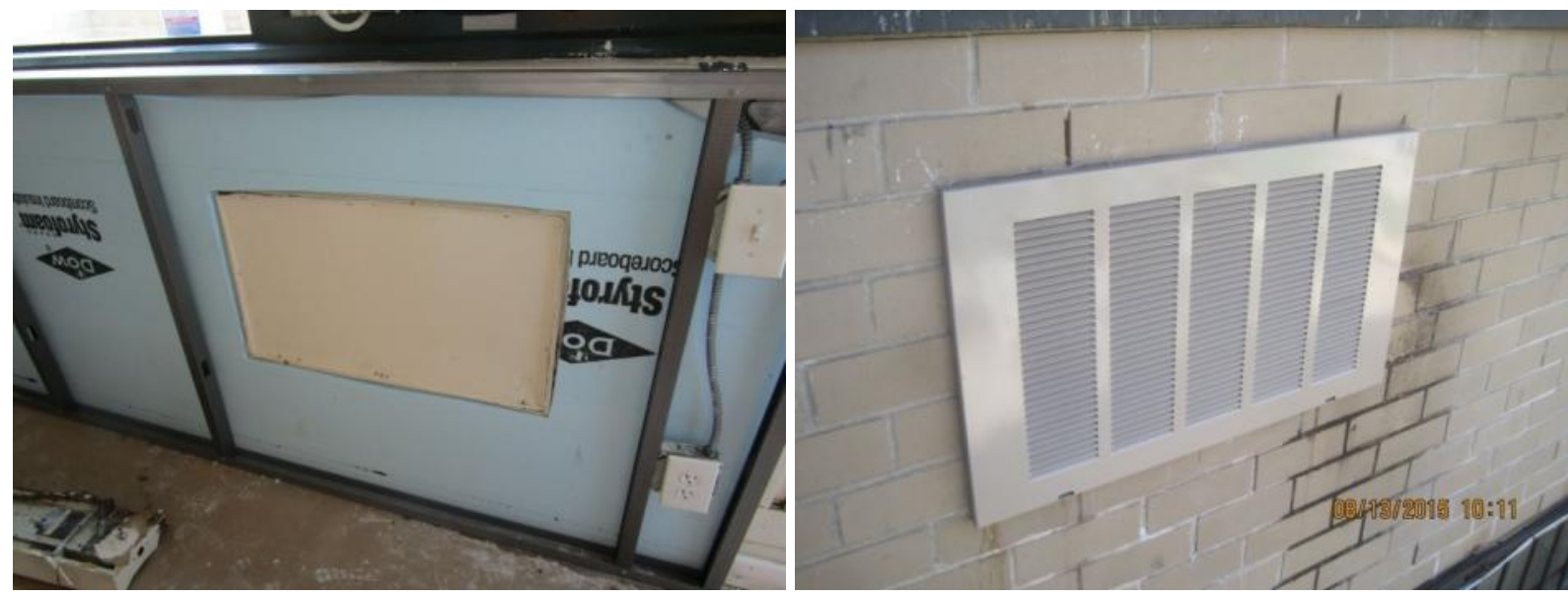

Figure 17. A metal cover was sealed to the sleeve opening (left), not shown is GWB covering the rigid insulation and sleeve cover; exterior louver (right)

Although the primary concern of this retrofit measure was air leakage around the through-wall AC sleeve, removing the through-wall AC units had another purpose. To further explain, the property is master-metered for electricity. Residents are charged for AC use monthly; the property management company visually inspects the property from the exterior to count AC units (Figure 18). So residents are charged for having ACs units installed whether or not they use the units. 


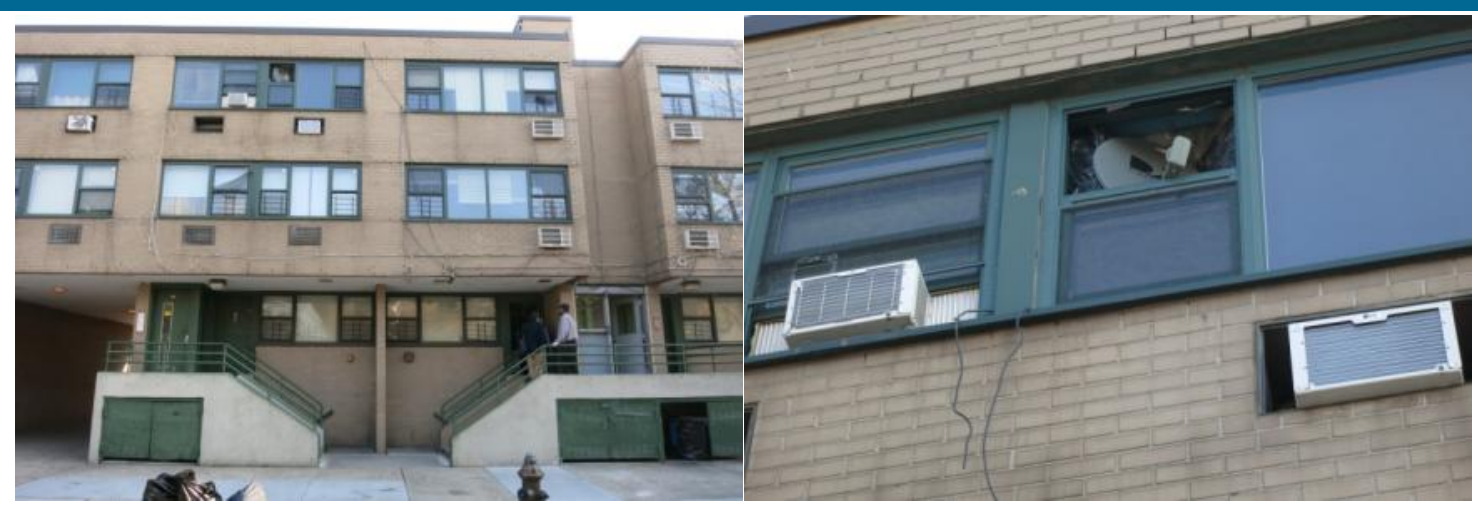

Figure 18. Street view of through wall and window AC units (left); close-up view of through-wall and window AC units (right)

Eliminating the sleeve units makes it easier to verify $\mathrm{AC}$ installation and charge residents accordingly. This method of AC charging encourages the residents to remove their ACs seasonally and reduces infiltration.

Replacing the exterior doors for the units facing the courtyard presents another opportunity to reduce exterior infiltration (Figure 19). These units currently have mail slots in the front doors instead of mailboxes; the units that are accessed from a common front door and stairwell have lobby-level interior mailboxes. The retrofit construction includes creating dedicated mailbox spaces for the ground-floor courtyard units that will eliminate the need for mail slots in the front doors.
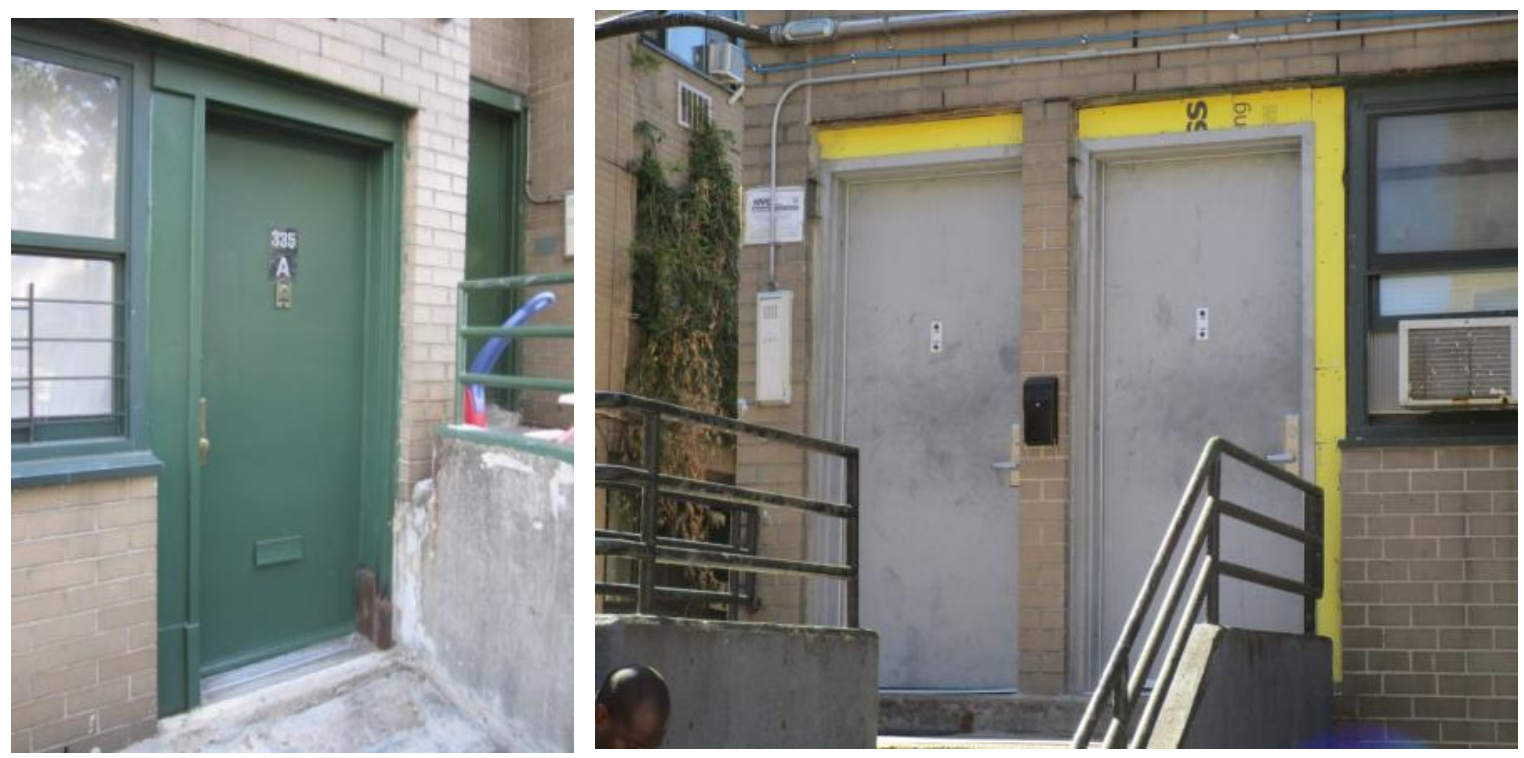

Figure 19. Mail slot at a courtyard-facing unit (left); new doors with wall-mounted mailboxes (right)

Unit-to-unit air transfer is also being addressed during apartment upgrades. On a unit-by-unit basis, air sealing is being done where relevant, such as at piping penetrations (Figure 20). 


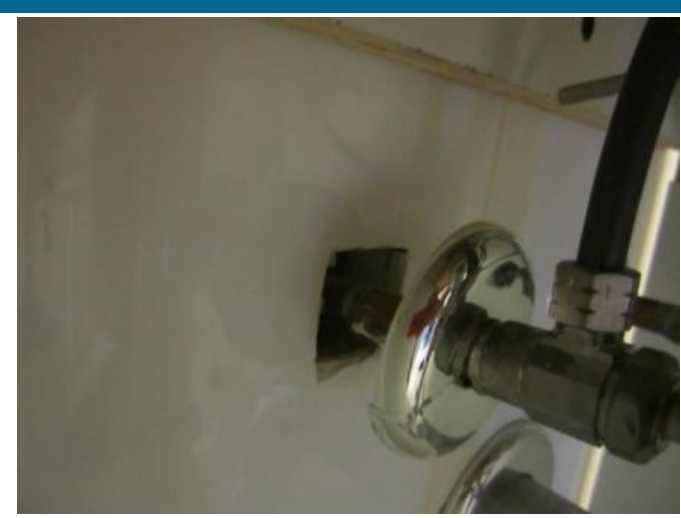

Figure 20.Typical in-unit plumbing penetration to be air sealed during bathroom upgrades

\subsection{Water}

In the seven DHW boiler rooms, the atmospherically vented water boilers (Figure 21) are being replaced with high-efficiency, direct-vent models (85\% efficient) and storage tanks. As of August 2015 the mechanical plan for DHW has not been finalized. Blocks that serve a smaller number of units may receive condensing boilers. Blocks that serve commercial spaces in addition to residential may receive a different configuration than the other blocks to allow for submetered heat and DHW to commercial tenants. Depending on the final selection of equipment, the fresh air ducts to the mechanical rooms, for combustion air, may be eliminated.

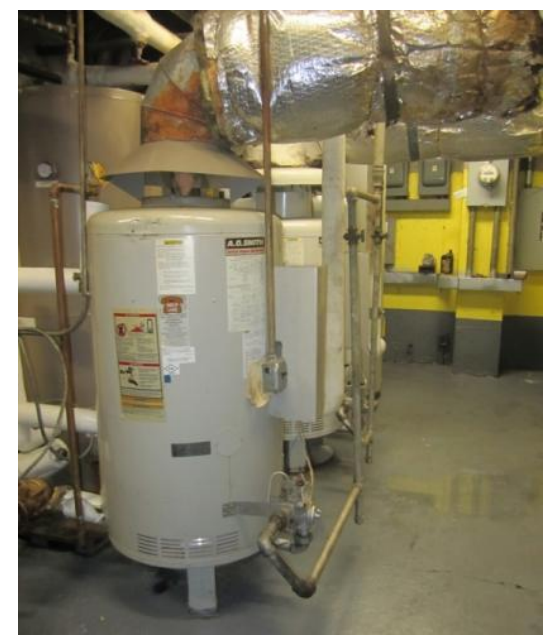

Figure 21. DHW heaters (note that the flue vent pipes have insulation, which is a code violation and a fire hazard)

Within the residential units, tamper-proof low flow fixtures are being installed including showerheads ( 1.5 gallons per minute), bathroom faucets (1 gallon per minute), and kitchen faucets (1.5 gallons per minute). Low-flow toilets are being installed as well.

\subsection{Ventilation}

At the roof level, fans are being repaired or replaced and ductwork repair and air sealing are being completed as needed. In the units, exhaust registers were removed and cleaned during bathroom renovations. If a bathroom has a scoop within the ventilation shaft, the scoop is being repaired as needed for functional operation (Figure 22). 

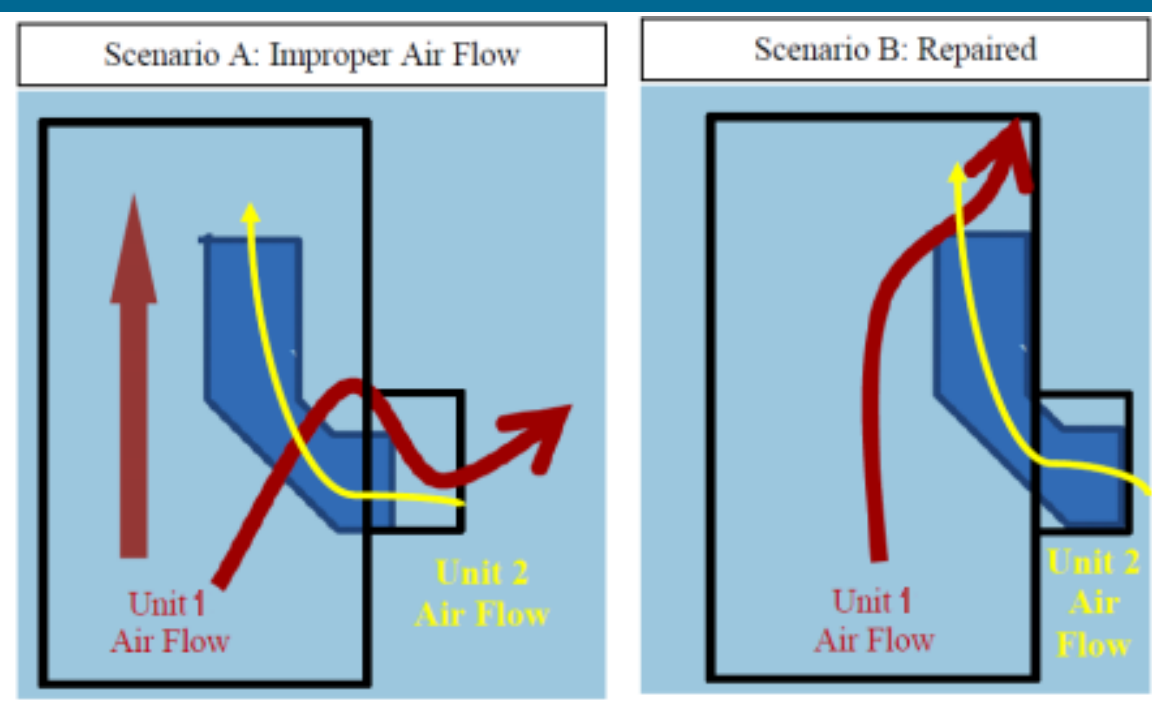

Figure 22. Scoop repair diagram: Scenario A shows how air can flow from one unit to another when the scoop is not positioned correctly. Scenario B shows how air from one unit cannot enter another unit when the scoop is positioned correctly.

\subsection{Common Area Lighting}

Interior and exterior lighting is being upgraded to LED bulbs with new fixtures as needed. The site lighting had not been replaced in some time (Figure 23). The 240 exterior lighting fixtures are to be controlled by photocell sensors. Interior common area lighting in the lobby and stairwell operates continuously for security purposes.

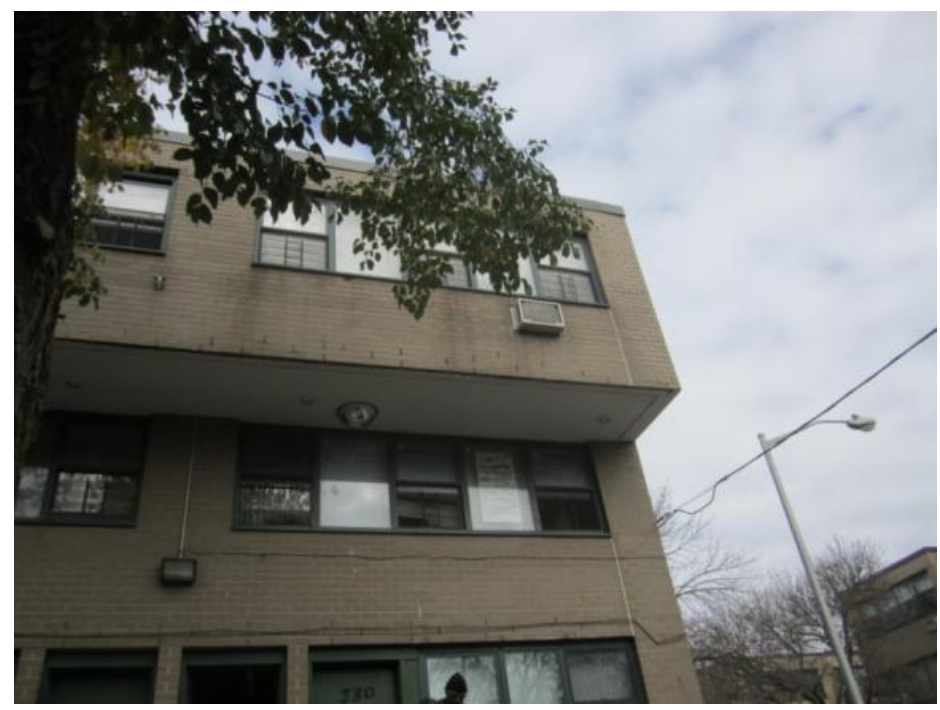

Figure 23. Existing site lighting: pole lights, wall packs, and recessed lights

The stairwells were dark gray and green, which made those spaces appear dark. Light levels were recorded to determine the effect of painting the stairwells a lighter color before new lighting fixtures were installed (Table 8). The results of this testing persuaded the owners to paint the stairwells a lighter color, which enhanced the brightness of these areas (Figure 24). 


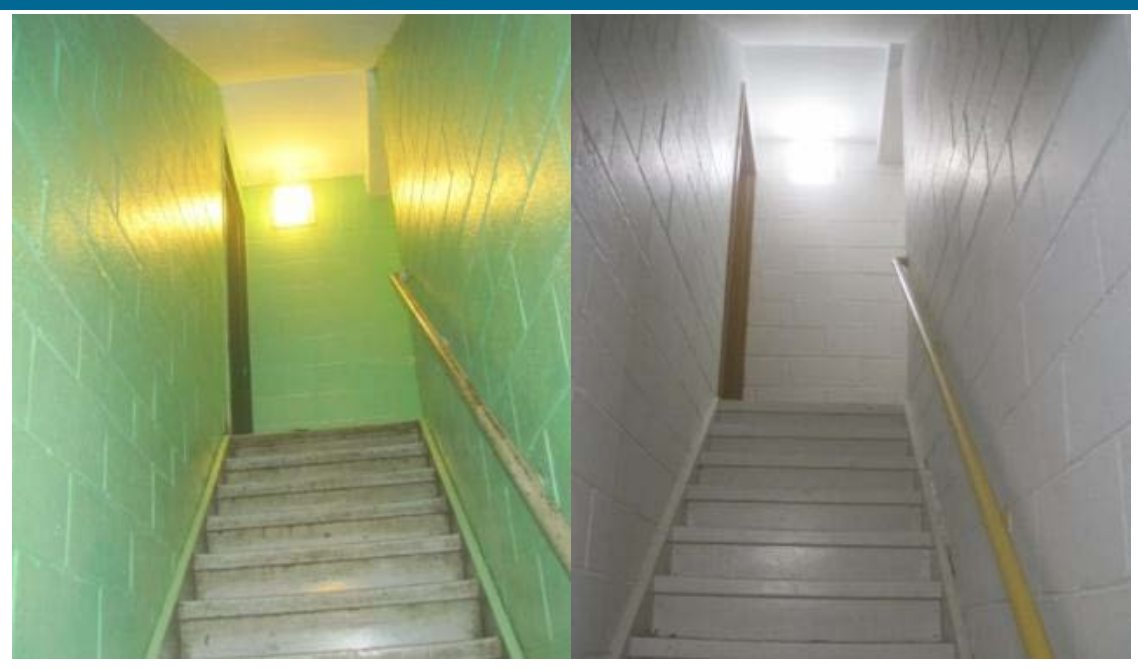

Figure 24. Existing stairwell lighting (left); newly installed stairwell lighting after paint color was changed (right)

Table 8. Lighting Levels in Building Common Areas

\begin{tabular}{c|c}
\hline Location & Illuminance (footcandles) \\
\hline Ltairwell Light Levels (green paint), Stairwell Contains 2 Existing Fixtures at the Landing \\
\hline Landing, $\mathbf{1}^{\text {st }}$ floor & 3 \\
Midstairway, Vestibule to $\mathbf{1}^{\text {st }}$ Floor & 0.5 \\
\hline Stairwell Light Levels (white paint), Stairwell Contains $\mathbf{2}$ Existing Fixtures at the Landing \\
\hline Location & Illuminance (footcandles) \\
Landing, $\mathbf{1}^{\text {st }}$ Floor & 5 \\
\hline Midstairway, Vestibule to $\mathbf{1}^{\text {st }}$ Floor & 1.5 \\
\hline Stairwell Light Levels (white paint), Stairwell Contains 2 New Fixtures at the Landing \\
\hline Location $^{\text {Landing, }} \mathbf{1}^{\text {st }}$ floor & Illuminance (footcandles) \\
\hline Midstairway, Vestibule to $\mathbf{1}^{\text {st }}$ Floor & 6.3 \\
\hline
\end{tabular}

In each unit, light fixtures were replaced in the kitchen, hall, and bathroom. These fixtures were updated with more efficient compact fluorescent lamps or LED fixtures. Figure 25 demonstrates the visible change in bathroom illumination with new light fixtures.

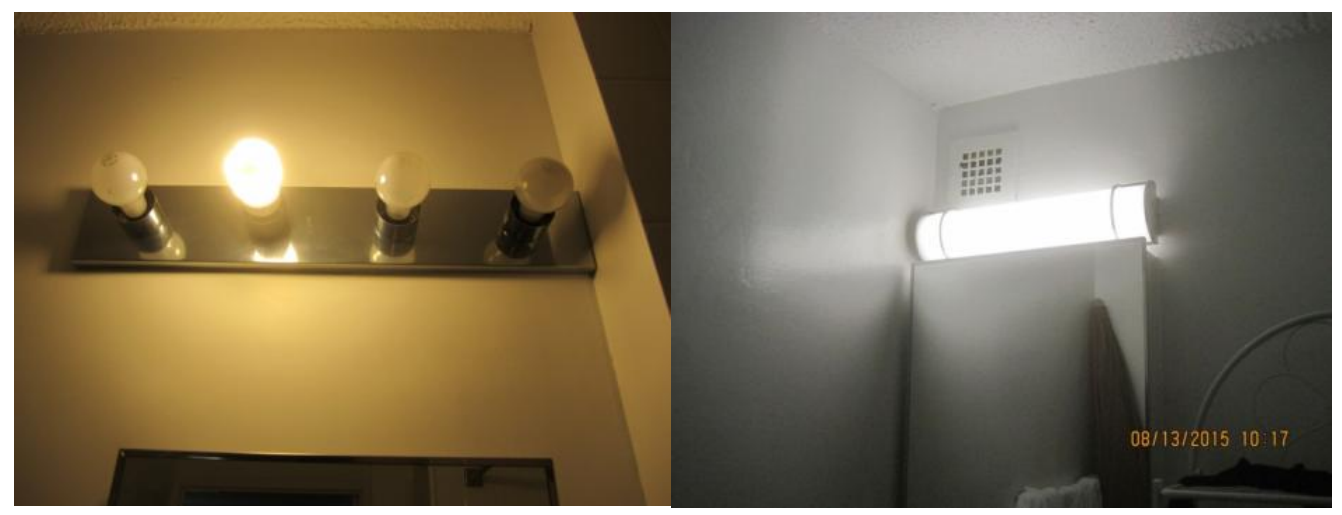

Figure 25. Sample in-unit bathroom lighting (left); replaced (right) 


\section{Discussion}

The single largest challenge for implementing energy-conservation measures at Marcus Garvey was working within occupied spaces. The building owner performed retrofit work on 40 units when they were unoccupied. All other units are being renovated while fully occupied. Residents were not moved to different units to allow for construction in a vacant unit.

Measures are being implemented in phases to minimize disruption. The wall insulation, sealing of the through-wall AC vent, and installation of new electric baseboards are conducted simultaneously to limit disruption to the living room space. Similarly, the kitchen work is done, then the bathroom. Cosmetic upgrades were also made.

Due to the scale of this project, the implementation of the retrofit is ongoing. CARB continues to work with the project team to ensure that the quality of the work is maintained throughout the project.

\subsection{Energy Savings}

Table 9 shows the composition of the modeled (Targeted Retrofit Energy Analysis Tool Version 3.0) electricity savings. Baseboard controls are estimated to save the most electricity, about 1 million $\mathrm{kWh}$. Wall insulation, air sealing, and refrigerator replacement were also substantial electricity savers, in the range of 150,000 to $450,000 \mathrm{kWh}$.

Table 9. Breakdown of Predicted Energy Savings

\begin{tabular}{|c|c|c|c|c|c|}
\hline & \multicolumn{3}{|c|}{ Annual Energy Savings } & \multirow[b]{2}{*}{$\begin{array}{c}\text { Demand } \\
\text { Savings } \\
(\mathrm{kW})\end{array}$} & \multirow[b]{2}{*}{$\begin{array}{c}\text { Source } \\
\text { Energy } \\
\text { Savings } \\
(\%)\end{array}$} \\
\hline Measures & $\begin{array}{l}\text { DHW } \\
\text { MBtu }\end{array}$ & $\begin{array}{c}\text { Cooling } \\
\text { kWh }\end{array}$ & $\begin{array}{c}\text { Non- } \\
\text { Cooling } \\
\text { kWh }\end{array}$ & & \\
\hline Air Sealing & 0 & $-29,250$ & 198,750 & -33.1 & $1.4 \%$ \\
\hline Wall Insulation & 0 & $-30,500$ & 436,250 & -34.4 & $3.4 \%$ \\
\hline Electric Baseboard Controls & 0 & 315,000 & 799,500 & 356.0 & $9.2 \%$ \\
\hline $\begin{array}{c}\text { Electric Baseboard Warm } \\
\text { Weather Shutdown }\end{array}$ & 0 & 0 & 216,000 & 0.0 & $1.8 \%$ \\
\hline DHW & 6,500 & 0 & 0 & 0.0 & $5.2 \%$ \\
\hline Exterior LEDs & 0 & 0 & 42,000 & 4.8 & $0.3 \%$ \\
\hline Unit Lighting & 0 & 23,250 & 44,500 & 35.6 & $0.6 \%$ \\
\hline Unit Refrigerators & 0 & 50,000 & 151,250 & 73.5 & $1.7 \%$ \\
\hline Unit Low Flow & 3,500 & 0 & 0 & 0.0 & $2.9 \%$ \\
\hline Total & 10,000 & 321,500 & $1,883,750$ & 394 & $26.5 \%$ \\
\hline
\end{tabular}

The cooling savings related to the electric baseboard controls were a result of the baseboard controls eliminating any summertime heating that was occurring in the existing condition configuration. The increase in cooling loads related to air sealing and wall insulation was a result of natural infiltration being minimized, so nighttime cooling benefits from air infiltrating now need to be made up through mechanical air conditioning. The decrease in cooling loads and 
increase in heating loads related to lighting and refrigerators resulted from reduced internal loads from these appliances.

\subsection{Cost Savings}

In addition to using a simple payback period to quantify cost-effectiveness, a savings-toinvestment ratio (SIR) was also utilized. This is a common metric in weatherization and retrofit programs. SIR is a unitless indicator of the savings generated over the lifetime of a measure divided by the initial retrofit investment. Values greater than 1 are considered beneficial. The SIR calculations provide in Table 10 assume a 25 -year lifetime for air sealing, wall insulation, and DHW; they assume a 15-year lifetime for other measures (including the combined total).

Table 10. Summary of Cost-Benefit Information

\begin{tabular}{|c|c|c|c|c}
\hline Measures & Cost & $\begin{array}{c}\text { Annual Cost } \\
\text { Savings }\end{array}$ & $\begin{array}{c}\text { Payback } \\
\text { (Years) }\end{array}$ & SIR \\
\hline Air Sealing & $\$ 380,000$ & $\$ 31,000$ & 12.5 & 2 \\
\hline $\begin{array}{c}\text { Wall Insulation } \\
\text { Electric Baseboard Controls }\end{array}$ & $\$ 944,000$ & $\$ 73,000$ & 12.9 & 1.9 \\
$\begin{array}{c}\text { Electric Baseboard Warm } \\
\text { Weather Shutdown }\end{array}$ & $\$ 6,500$ & $\$ 39,000$ & 0.2 & 90 \\
\hline DHW & $\$ 1,000,000$ & $\$ 51,000$ & 19.6 & 1.3 \\
\hline Exterior LEDs & $\$ 60,000$ & $\$ 7,600$ & 7.9 & 1.9 \\
\hline Unit Lighting & $\$ 203,000$ & $\$ 12,000$ & 16.9 & 0.9 \\
\hline Unit Refrigerators & $\$ 283,000$ & $\$ 36,000$ & 7.8 & 1.9 \\
\hline Unit Low Flow & $\$ 31,500$ & $\$ 29,000$ & 1.1 & 13.8 \\
\hline Total & $\$ 3,687,500$ & $\$ 479,600$ & 7.7 & 2 \\
\hline
\end{tabular}

Based on SIR, the electric baseboard warm weather shutdown was by far the best investment. This measure is especially cost beneficial in that it does not seek to improve efficiency when consuming energy, but simply provides controls to not heat unnecessarily, which avoids the energy consumption altogether. Surprisingly, the least-beneficial measure based on this SIR analysis was for the in-unit compact fluorescent lamps, but this was because the fixtures were updated along with bulbs being replaced. 


\section{Conclusions}

- What are potential solution packages to achieve 30\% source energy savings over existing conditions in concrete garden-style apartments faced in brick?

Measure packages involving the conversion of the space-heating system from electric baseboards to either a gas-fired hydronic baseboard or ductless heat pump system both showed source energy savings greater than $30 \%$. However, neither option was selected for implementation because of the initial capital cost, magnitude of construction and disruption for the hydronic system, and unfamiliarity with the heat pump technology.

- What is the maximum cost-effectiveness of the solution package for achieving $30 \%$ source energy savings?

Simulations predict that the measure package implemented will yield a source energy savings of $26.5 \%$. At a cost of about $\$ 3.7$ million and utility bill savings of nearly $\$ 480,000$, this package was deemed cost-effective with a simple payback of 7.7 years. This scope was also successfully carried out in an occupied 625-unit complex. Reducing energy use by more than $25 \%$ in an occupied space further demonstrates the scope's replicability. The $30 \%$ packages could be implemented but might require more resident disruption and come at high first costs.

- How effectively can this solution package be replicated in other apartment buildings in Climate Zone 4A?

The measure package implemented is very replicable, because it is cost-effective, practical for implementation in occupied apartments, and it is expected to provide consistent savings because the measures implemented are not new or complex. The owners of this property feel comfortable with the scope of work they undertook and have already replicated some of the measures in other properties with confidence in the results. The scope was comprehensive and introduced the owners to new technology, specifically the electric baseboard controls. The owners have already installed these controls at some of their other properties. They will continue to do so to realize additional benefits from the insulation retrofits already completed in these other properties.

\subsection{Next Steps}

As of August 2015, the retrofit work was more than 50\% complete. Utility bill analysis will be performed 1 year post construction by both NYSERDA and SWA to verify that the projected energy savings was achieved. In addition to utility bill analysis, energy-conservation measures will continue to be inspected and tested during and post construction. Results will be compared to projections and existing conditions to measure improvements. 


\section{References}

Efficiency Maine. 2013. "Energy Efficient Heating Options: Pilot Projects and Relevant Studies.” April 8, 2013. Augusta, Maine. Accessed 8/21/2015:

www.efficiencymaine.com/docs/EMT_Energy-Efficient-Heating-Options-Report 2013 4 8.pdf. 
